\title{
Effect of Natural and Bio-Fertilizers on Productivity and Quality of Table Beet (Beta vulgaris L.) Grown in Sandy Soil at Siwa Oasis, Egypt
}

\author{
El-Sayed, M. A. M, ${ }^{1}$ M.F. Attia and M. R, Hafez ${ }^{2}$
}

\begin{abstract}
A field experiment was conducted on table beet (Detrweet cv.) throughout two consecutive winter seasons of 2015/2016 and 2016/2017 in Khimisah experimental farm which is located at the latitude of $29^{\circ} 12^{\prime} 34.5 \mathrm{~N}^{\prime \prime}$, and the longitude of $25^{\circ} 24^{\prime} 2.56^{\prime \prime}$ E., at Siwa Research Station, Matrouh Governorate, Desert Research Center, Cairo, Egypt. The field experiment was conducted in a randomized complete block design with split plot. The main factor was the mineral fertilizer (MF) at $62 \mathrm{kgP}_{2} \mathrm{O}_{5}+$ $100 \mathrm{kgK}_{2} \mathrm{O} / \mathrm{fed}$ as calcium super phosphate $\left(15.5 \% \mathrm{P}_{2} \mathrm{O}_{5}\right)+$ potassium sulfate $\left(50 \% \mathrm{~K}_{2} \mathrm{O}\right)$ i.e. recommended dose (RD), $62 \mathrm{kgP}_{2} \mathrm{O}_{5}$ as rock phosphate $(\mathrm{RP}), 100 \mathrm{kgK}_{2} \mathrm{O} / \mathrm{fed}$ as rock feldspar (RK) and RP+RK, while the sub main factor have been dedicated to the bio-fertilizers (BF) treatments i.e. without inoculation, with phosphate dissolving bacteria (PDB), with potassium solublizing bacteria (KSB) and PDB+KSB.
\end{abstract}

Results indicated that the most effective treatment was the interaction between $(\mathrm{RP}+\mathrm{RK})+(\mathbf{P D B}+\mathrm{KSB})$ produced the highest significant values of growth, root yield and quality, beside available $P$ and $K$ in soil and their content and uptake by table beet plants as well as, the microbial densities and dehydrogenase activity in the rhizosphere of table beet. This treatment also resulted in the maximum total net profit and the maximum total benefit cost ratio "BCR" (i.e. total income/total cost) (4.32) as compared to the other treatments.

It can be concluded that the application of natural $P$ and $K$ rocks fertilizers in combination with $P$ and $K$ solubilizing bacteria in sandy soil such as Khimisah soil will increase soil available and plant uptake of nutrients, yield and quality close to those obtained by chemical phosphorus and potassium application. Thus, replacing these chemical phosphorus and potassium fertilizers by natural one will help in reducing environmental pollution, cheaper in price and produce safe human food especially in Siwa Oasis which is nature reserve.

Key words: Rock phosphate, Rock feldspar, P and $\mathrm{K}$ available and uptake, bio-fertilizers, table beet plant.

\section{INTRODUCTION}

Siwa Oasis is located in the Northern part of the Western Desert in Egypt. It has a cultivated area around 30,000 fed. Agriculture is the main human activity in Siwa Oasis and is depending on the surface irrigation system by groundwater in most areas (EI-Naggar, 2010).
Siwa Oasis has a continental climate that is very cold in winter and very hot in summer.

Table beet does not occupy any agricultural area in Siwa Oasis despite its importance for health especially if it is organic product. Red beet (Beta vulgaris L.) has a good storability led to availability of fresh product around the year without a need for applying expensive storage equipments. As red beets are widely used in food industry, this generates farmers' interest, including those specializing in sustainable technologies of production. For many years, organic products received consumers interest for their health properties due to the high contents of minerals, vitamins, and pigments, that having beneficial effects on human (Szura et al. 2008, Zujko and Witkowska 2009 and Hunter et al. 2011). The fertilizer application for crops should be in adequate levels of all nutrients as it is very essential for top quality and yield.

As the world's human population continues to increase, the demands placed upon agriculture to supply future food will be one of the greatest challenges facing the agrarian community. In order to meet this challenge, a great deal of effort focusing on the soil biological system and the agro-ecosystem as a whole is needed to understand better the complex processes and interactions governing the stability of agricultural land. There is, therefore, an urgent need for increase the food production by around $50 \%$ in the next 20 years in order to sustain the population pressure (Vasil, 1998; Leisinger, 1999).

However, the recent major problem facing the farmers is the high cost of chemical fertilizers. The alternative to depending on expensive imported fertilizers is to exploit indigenous resources such as $\mathrm{P}$ and i.e. $\mathrm{K}$ bearing minerals rock phosphate and feldspar or bio-fertilizers.

Phosphorus plays an important role in the most metabolic processes especially in biosynthesis and translocation of carbohydrates. It is very important for developing the fruits and the deficiency appeared in terms of decline on the yield and an adverse effect on fruits quality (Yagodin, 1990). On the Roselle plant, Abdel-Kader and Saleh (2017) reported that the highest growth and yield were obtained from plants treated with $200 \mathrm{~kg} / \mathrm{fed}$ rock phosphate plus phosphate dissolving

\footnotetext{
${ }^{1}$ Soil Fertility and Microbiology Dept, Desert Research Center, Cairo, Egypt

${ }^{2}$ Plant Production Dept., Desert Research Center, Cairo, Egypt

Received November 20, 2018, Accepted December 23, 2018
} 
bacteria (PDB) in the first experiment and $350 \mathrm{~kg} / \mathrm{fed}$ feldspar plus potassium solubilizing bacteria (KSB) in the second experiment. Generally, the results suggested that the use of biofertilizer with rock phosphate or with feldspar is economic and environmental friendly and has potential to improve Roselle yield and quality.

Potassium is essential for many plants metabolic processes. It plays many important regulatory roles in plant development (Miller et al., 1990). Aparna (2001) added that, $\mathrm{K}$ is considered the most important cation of its physiological and chemical functions. This could be because $\mathrm{K}^{+}$is usually absorbed as a single charge cation by an active mechanism and translocated along electrochemical potential gradient (Roghieh and Arshad, 2009). Potassium is essential for growth, maintains cell turgidity and to regulate the water content of plants (Rengel and Damon, 2008). Potassium fertilizer exhibited a significant effect on vegetative characters and physical properties of beet roots, while the $\mathrm{Na}$ content level and the productivity of roots yield and recoverable sugar yield were insignificant, (ton/fad) (Ferweez et al., 2018).

Mineral fertilizers and other chemicals that commonly used in agricultural production, not only have harmful effects on the environment, but also they can alter the composition of fruits, vegetables and root crops (Bogatyre, 2000).

Application of natural alternative fertilizers such as rock phosphate $\left[\mathrm{Ca}_{10}\left(\mathrm{PO}_{4}\right)_{4} \mathrm{~F}_{2}\right]$ (RP) and potassium feldspars $\left(\mathrm{KAISi}_{3} \mathrm{O}_{8}\right)(\mathrm{RK})$ may be agronomically more useful and environmentally more feasible than soluble $\mathrm{P}$ and K (Rajan et al., 1996). The alternative use of natural elements compounds improving soil physical and chemical properties as well as increasing water uptake and nutrient availability (Eman et al., 2010). Natural elements compounds as rock phosphate and feldspar are used as sources for some nutrient minerals that is considered as clean agriculture. Besides these natural minerals, others bear major essential macronutrients (i.e. $\mathrm{P}$ and $\mathrm{K}$ ) are required for plant growth and development to optimize yield and improve quality of production. Thus, the uses of alternative indigenous resources such as feldspar and rock phosphate are gaining importance to alleviate the dependence of import or costly commercial fertilizers (Badr et al., 2006; Hassan et al.2016).

The use of plant growth promoting rhizobacteria (PGPR), including phosphate solubilizing and potassium solubilizing bacteria as bio-fertilizers, was suggested as a sustainable solution to improve the plants nutrition and production (Vessey 2003). Increasing the bioavailability of $\mathrm{P}$ and $\mathrm{K}$ in soils with inoculation of PGPR or combined inoculation with rock materials may lead to increase $\mathrm{P}$ and $\mathrm{K}$ uptake and plant growth, (Lin et al. 2002; Sahin et al. 2004; Girgis, 2006 and Eweda et al. 2007).

Phosphate solubilizing bacteria have been used to convert insoluble phosphate compounds such as rock phosphate into a soluble form that is available for plant uptake. These bacteria produce organic compounds that convert the unavailable $\mathrm{P}$ form to an available one. In addition, in the same manner potassium solubilizing bacteria have the ability to dissolve $\mathrm{K}$ from minerals containing $\mathrm{K}$, such as feldspar into an available form. The sole or dual application minerals containing $\mathrm{P}$ and $\mathrm{K}$ as rock phosphate and feldspar in combination with the $\mathrm{P}$ and $\mathrm{K}$ solubilising bacteria provides the growing plants with a continuous supply of phosphorus and potassium for a best plant growth rate (Han and Lee; 2005). The direct application of natural sources of $P$ and $\mathrm{K}$ such rock phosphate and feldspar $\mathrm{P}$ and $\mathrm{K}$ minerals to soils may be more economically feasible than mineral chemical fertilizers (Rajan et al.; 1996). Studies on Roselle plants indicated that co-inoculation of PDB (Bacillus megaterium var. phosphaticum) and KSB (Bacillus mucilaginosus) in conjunction with direct application of rock phosphate at rates of 200 and 250 $\mathrm{kg} / \mathrm{fed}$ and feldspar at rates of 350 and $450 \mathrm{~kg} / \mathrm{fed}$ respectively, into the soil, significantly increased the growth characteristics along with yield compared to chemical PK and other treatments (Abdel-Kader and Saleh 2017).

Using of $\mathrm{P}$ and $\mathrm{K}$ solubilizing bacteria as biofertilizers has become a practical solution to supply the plants with both nutrients (Badar; 2006). The coinoculation of $\mathrm{K}$ and $\mathrm{P}$ solubilizing bacteria increased the soil phosphorus availability from 12 to $21 \%$ and the potassium availability from 13 to $15 \%$ as well as it improved their uptake by plants. In addition, the harvested biomass and yield of the treated plants were increased by $23-30 \%$ over the control (Han et al.; 2006).

Abou El Seoud and Abdel-Megeed (2012) stated that co-inoculation of PDB and KSB in conjunction with direct application of rock $\mathrm{P}$ and $\mathrm{K}$ materials into the soil increased $\mathrm{P}$ and $\mathrm{K}$ availability and uptake. Basha and Hassan (2017) concluded that the direct application of mineral phosphorus and potassium combined with phosphate and potassium dissolving bacteria to the sandy loam soil improved phosphorus and potassium availability in the soil and improve growth parameters of canola plants significantly compared with the control.

The aims of this study were to evaluate the efficiency of rock phosphate and potassium feldspar applications combined with phosphate and potassium solubilizing bacteria on the availability of $\mathrm{P}$ and $\mathrm{K}$ and their uptake 
on growth, yield and quality of table beet plant grown in sandy soil at Siwa Oasis.

\section{MATERIALS AND METHODS}

A field experiment was carried out during the winter seasons of 2015/2016 and 2016/2017 on Khimisa experimental farm which is located at the latitude of $29^{\circ} 12^{\prime} 34.5 \mathrm{~N}^{\prime \prime}$, and the longitude of $25^{\circ} 24^{\prime} 2.56^{\prime \prime} \mathrm{E}$., Siwa Research Station, Desert Research Center, Egypt, in a randomized complete block design with split plot. The main factor was the mineral fertilizer (MF) at $62 \mathrm{kgP}_{2} \mathrm{O}_{5}+100 \mathrm{kgK}_{2} \mathrm{O} / \mathrm{fed}$ as calcium superphosphate $\left(15.5 \% \mathrm{P}_{2} \mathrm{O} 5\right)+$ potassium sulfate $\left(50 \% \mathrm{~K}_{2} \mathrm{O}\right)$ i.e. recommended dose (RD), $62 \mathrm{kgP}_{2} \mathrm{O}_{5}$ as rock phosphate (RP), $100 \mathrm{kgK}_{2} \mathrm{O} /$ fed as rock feldspar (RP) and $\mathrm{RP}+\mathrm{RK}$, while the sub main factor has been dedicated to the biofertilizers (BF) treatments i.e. without inoculation, with phosphate dissolving bacteria (PDB), with potassium solublizing bacteria $(\mathrm{KSB})$ and $\mathrm{PDB}+\mathrm{KSB}$. Bacterial strains were applied separately or in combination as soil treatment. Table beet seeds were treated before planting with individual or mixture of bacterial suspensions for 3 hrs before transplanting (carboxy methyl cellulose $0.5 \%$ was used as an adhesive agent).

Some physical and chemical properties of the experimental soil and irrigation water are shown in Table 1.

Rock phosphate (RP) $\left(\mathrm{P}_{2} \mathrm{O}_{5} 12.5 \%, \mathrm{~K}_{2} \mathrm{O} 0.31 \%\right.$, $\mathrm{SiO}_{2} 7.9 \%, \mathrm{CaO} 41.22 \%, \mathrm{Al}_{2} \mathrm{O}_{3} 0.41 \%$ ), while rock potassium feldspar $\left(\mathrm{K}_{2} \mathrm{O} 10.1 \%, \mathrm{P}_{2} \mathrm{O}_{5} 0.10 \%, \mathrm{SiO}_{2}\right.$ $66.12 \%, \mathrm{CaO} 0.2 \%, \mathrm{Al}_{2} \mathrm{O}_{3} 17.59 \%$ ) were obtained from Abo Tartor Mountain, Kharga region, Western Desert, Egypt.

Rock phosphate $\left(\begin{array}{lll}12.5 \% & \mathrm{P}_{2} \mathrm{O}_{5}\end{array}\right)$ and potassium feldspar $\left(10.1 \% \mathrm{~K}_{2} \mathrm{O}\right)$ were added at a levels 500 and $1000 \mathrm{~kg} / \mathrm{fed}$., respectively, and mixed thoroughly with the soil in each plot. The treatments of $\mathrm{P}$ and $\mathrm{K}$ chemical fertilizers were done by the full recommended dose (RD) of chemical phosphorus at $62 \mathrm{~kg} \mathrm{P}_{2} \mathrm{O}_{5} /$ fed. as $400 \mathrm{~kg}$ of calcium superphosphate, $15.5 \% \quad \mathrm{P}_{2} \mathrm{O}_{5}$, and potassium at $100 \mathrm{~kg} \mathrm{~K}_{2} \mathrm{O} / \mathrm{fed}$. as $200 \mathrm{~kg}$ potassium sulphate and $50 \% \mathrm{~K}_{2} \mathrm{O}$. All plots received nitrogen at $60 \mathrm{~kg} \mathrm{~N} / \mathrm{fed}$ as ammonium sulphate $(20.5 \% \mathrm{~N})$ and $20 \mathrm{~m}^{3}$ of compost.

Seeds of table beet (Detrweet cv.) were sown on the middle of October 2015 and 2016 seasons with 2-3 balls per hill using dry sowing method on two sides of the irrigation line of the ridge, the planting within six lines for each ridge and $10 \mathrm{~cm}$ apart among plants. The area for each net experimental plot was $1 / 400$ fed $(10.5 \times 1.0$ $\mathrm{m})$.

The calcium superphosphate, rock phosphate and potassium feldspar were mixed with compost and incorporated into soil surface two weeks before planting. The chemical analysis of the applied compost showed the flowing values: $\mathrm{pH} 6.76$, EC $2.85 \mathrm{dSm}^{-1}$, Total $\mathrm{N}$ $1.22 \%$, total P $0.24 \%$, total K $0.64 \%$, C/N 17.33 .

The biofertilizer treatments were applied with the planting of table beet and repeated after 30 days of germination, as a soil inoculation in the form of bacterial suspensions $\left(10^{8} \mathrm{cfu} / \mathrm{ml}\right)$ with Carboxy methyl cellulose $(0.5 \%)$ as an adhesive agent.

Potassium sulfate $\left(48 \% \mathrm{~K}_{2} \mathrm{O}\right)$ was applied as a side dressing in two equal doses at 40 and 70 days from sowing. Nitrogen fertilizer was applied as ammonium sulphate $(20.5 \% \mathrm{~N})$ at the rate of $300 \mathrm{~kg} / \mathrm{fed}$. and equally divided for five times after 20,30,40, 50 and 60 days from planting. The common agricultural practices for growing table beet were applied according to the recommendations of Ministry of Agriculture. Table beet plants were harvested after 80 days from sowing date.

Table 1. Some physical and chemical properties of the experimental soil during the two successive growing seasons and some chemical properties of irrigation water

\begin{tabular}{|c|c|c|c|c|c|c|c|c|c|c|c|c|}
\hline \multirow{2}{*}{$\begin{array}{l}\text { Soil } \\
\text { properties }\end{array}$} & \multirow{2}{*}{$\begin{array}{l}\text { Coarse } \\
\text { sand \% }\end{array}$} & \multirow{2}{*}{$\begin{array}{l}\text { Fine } \\
\text { sand } \%\end{array}$} & \multirow{2}{*}{$\begin{array}{l}\text { Silt } \\
\%\end{array}$} & \multirow{2}{*}{$\begin{array}{l}\text { Clay } \\
\%\end{array}$} & \multirow{2}{*}{$\begin{array}{l}\text { Soil } \\
\text { texture }\end{array}$} & \multicolumn{2}{|c|}{$\begin{array}{c}1: 2.5 \\
\text { (soil to water } \\
\text { extraction) }\end{array}$} & \multirow{2}{*}{$\begin{array}{r}\text { Organic } \\
\text { matter } \\
(\mathrm{g} / \mathrm{kg})\end{array}$} & \multirow{2}{*}{$\begin{array}{r}\mathrm{CaCO}_{3} \\
(\mathrm{~g} / \mathrm{kg})\end{array}$} & \multirow{2}{*}{$\begin{array}{r}\text { Total N } \\
(\mathrm{g} / \mathrm{kg})\end{array}$} & \multicolumn{2}{|c|}{$\begin{array}{r}\text { Available } \\
\text { (ppm) }\end{array}$} \\
\hline & & & & & & pH & $\begin{array}{c}\text { EC } \\
\left(\mathbf{d S m}^{-1}\right)\end{array}$ & & & & $\mathbf{P}$ & $\mathbf{K}$ \\
\hline Season1 & 45.7 & 29.7 & 20.1 & 4.4 & $\begin{array}{l}\text { Sandy } \\
\text { soil }\end{array}$ & 7.28 & 1.42 & 6.1 & 22.4 & 2.3 & 13.25 & 96 \\
\hline Season2 & 46.0 & 28.9 & 19.9 & 5.2 & $\begin{array}{l}\text { Sandy } \\
\text { soil }\end{array}$ & 7.18 & 1.58 & 6.7 & 22.8 & 2.8 & 14.05 & 106 \\
\hline \multirow{3}{*}{\multicolumn{2}{|c|}{$\begin{array}{l}\text { Irrigation water } \\
\text { chemical analysis }\end{array}$}} & EC & nl & $\mathbf{S}$ & \multicolumn{4}{|c|}{ Soluble Cations in mmoLcL ${ }^{-1}$} & \multicolumn{4}{|c|}{ Soluble Anions in $\mathrm{mmoLcL}^{-1}$} \\
\hline & & $\left(\mathrm{dSm}^{-1}\right)$ & pin & SAK & $\mathrm{Na}^{+}$ & $\mathbf{K}^{+}$ & $\mathbf{C a}^{++}$ & $\mathbf{M g}^{++}$ & $\mathrm{CO}_{3}^{--}$ & $\mathrm{HCO}_{3}^{-}$ & $\mathrm{Cl}^{-}$ & $\mathrm{SO}^{-}{ }_{4}$ \\
\hline & & 3.60 & 7.45 & 12.92 & 27.40 & 0.60 & 3.30 & 5.70 & $\mathrm{Nd}$ & 3.50 & 22.00 & 11.50 \\
\hline
\end{tabular}




\section{The scored parameters:}

\section{Vegetative growth parameters}

After 70 days of planting, plant samples were taken for the determination of vegetative growth characters. The roots were thoroughly washed with running water and were separated from the shoots. Data for plant height, fresh and dry weights of shoots and roots were recorded. The dried plant samples were pulverized and analyzed for phosphorus and potassium contents in shoots and roots.

\section{Yield parameters:}

At the harvest date, the plants of one row from each plot were harvested to estimate yield parameters: root fresh weight (g/plant), root dry weight ( $\mathrm{g} / \mathrm{plant})$, root length $(\mathrm{cm})$, root diameter $(\mathrm{cm})$, root dry yield (MT/fed), shoot length $(\mathrm{cm})$, shoot fresh weight (g/plant), shoot dry weight (g/plant), plant length $(\mathrm{cm})$, plant fresh weight $(\mathrm{g})$, plant dry weight $(\mathrm{g})$. The content of ascorbic acid in roots was determined by using iodate method as described by Samotus et al. (1985). Total soluble solids percentage (T.S.S. \%) was measured in roots according to A.O.A.C. (1985).

\section{Soil analysis:}

Soil samples were collected from each plot at the same time of plant sampling, air-dried, passed through a $2 \mathrm{~mm}$ sieve and kept for analysis. Particle size distribution was determined using the pipette method according to Jackson (1973). Electrical conductivity (EC) and soil $\mathrm{pH}$ was determined in a 1: 2.5 soil to water extract using conductivity meter and Beckman $\mathrm{pH}$ meter, respectively according to Jackson (1973) and McLean (1982). Organic carbon content was determined by Walkely and Black's wet oxidation method, total calcium carbonate was determined by Scheibler calcimeter, available potassium was extracted by neutral normal ammonium acetate method and measured by flame photometer and the extracted $\mathrm{P}$ (using $0.5 \mathrm{M}$ $\mathrm{NaHCO}_{3}$ at pH 8.5 according to Olsen et al., 1982) was measured colorimetrically using the chlorostannus phosphomolybdic-sulfuric acid method as described by according to Jackson (1973).

\section{Determination of microbial activity:}

Counts of microorganisms were estimated by the dilution plate technique methods (Becky et al., 2001). The following microbial analyses (i.e., total bacterial count (TBC), phosphate dissolving bacteria (PDB), potassium solubilizing bacteria (KSB), Total nitrifying bacterial count (TNBC) and total thermophilic bacterial count (TTBC), were carried out in all soil samples according to Pious et al. (2015).
Dehydrogenase activity ( $\mu \mathrm{g}$ TPF $\mathrm{g}^{1}$. dry soil $24 \mathrm{~h}$.) in rhizosphere soil was determined according to Pramer and Schmidt (1964) and Thalmann (1967). Nitrifies were enriched on according to Hirotsugu et al. (2015), Nitrifying bacteria were enumerated by the MPN technique using both modified media of Maite et al., (2005). As a control, nitrite and nitrate were assayed using the standard chemical method (Griess-Ilosvay reagent) by Zhao et al. (2015) after 8 weeks of seeding.

\section{Plant analysis:}

All samples from root and shoot were dried at $70{ }^{\circ} \mathrm{C}$ oven for $48 \mathrm{hr}$. and were finely grinded. A half gram of ground table beet roots was digested using $10 \mathrm{ml}$ of $\mathrm{H}_{2} \mathrm{SO}_{4}$ and $2 \mathrm{ml}$ of perchloric acid in a conical flask as described by Chapman and Pratt (1961) and the digests were used to determine total phosphorus spectrophotometrically by chlorostannusphosphomolybdic sulfuric acid method as described by Jackson (1973). Potassium was determined by using the flame photometer method as described by Knudsen $e t$ al. (1982).

\section{Statistical and Economic analysis:}

The experiment was conducted as a randomized complete block design with split plot technique in three replications. All data were statistically analyzed according to the technique of analysis of variance (ANOVA) as published by Gomez and Gomez (1984), using "SAS 9.1.3" Computer software package. Least Significant Differences (LSD) at 5\% was used to test the differences between treatment means. For economic analysis, benefit to cost ratio (BCR) was calculated for all the treatments using prevailing prices of inputs and table beet yield, $\mathrm{BCR}=($ Total income $) /($ Total cost $)$ (Idrees et al., 2018).

\section{RESULTS AND DISCUSSION}

\section{Vegetative Growth Parameters:}

Table 2 show that there were significant differences among most of all mineral fertilizer treatments (MF) i.e. chemical and natural fertilizers where the dual soil application of RP+RK achieved the highest values (14.92 and 16.92), (272.76 and 342.91), (40.99 and 69.63), (18.33 and 23.17), (534.90 and 634.68) and (101.17 and 139.91) for shoot length $(\mathrm{cm})$, shoot fresh weight (g/plant), shoot dry weight (g/plant), plant length $(\mathrm{cm})$, plant fresh weight $(\mathrm{g})$ and plant dry weight $(\mathrm{g})$ in the first and second seasons, respectively. On the other hand, soil application of RP had the lowest significant effect on all vegetative growth parameters. 
Table 2. Effect of mineral natural and bio-fertilizers on vegetative growth parameters of table beet plant grown at two growth seasons.

\begin{tabular}{|c|c|c|c|c|c|c|c|c|c|c|}
\hline \multirow{2}{*}{$\begin{array}{c}\text { Season } \\
\text { *Mineral fertilizer } \\
(\mathrm{MF}) \\
* * \text { Biofertilizer }(\mathrm{BF}) \\
\end{array}$} & \multicolumn{5}{|c|}{ Season 2016} & \multicolumn{5}{|c|}{ Season 2017} \\
\hline & RD & $\mathbf{R P}$ & RK & $\mathbf{R P}+\mathbf{R K}$ & Mean & RD & $\mathbf{R P}$ & RK & $\mathbf{R P}+\mathbf{R K}$ & Mean \\
\hline \multicolumn{11}{|c|}{ Shoot length $(\mathrm{cm})$} \\
\hline Without inoculation & 12.33 & 6.33 & 10.00 & 13.00 & 10.42 & 12.33 & 8.67 & 10.67 & 14.33 & 11.50 \\
\hline Inoculation with PDB & 14.00 & 8.67 & 10.67 & 15.67 & 12.25 & 14.00 & 10.33 & 13.33 & 17.67 & 13.83 \\
\hline Inoculation with KSB & 13.00 & 8.33 & 12.00 & 14.67 & 12.00 & 13.00 & 9.67 & 12.00 & 17.00 & 12.92 \\
\hline $\begin{array}{l}\text { Inoculation with } \\
\mathrm{PDB}+\mathrm{KSB}\end{array}$ & 15.67 & 9.33 & 13.00 & 16.33 & 13.58 & 17.00 & 10.67 & 14.33 & 18.67 & 15.17 \\
\hline Mean & 13.75 & 8.17 & 11.42 & 14.92 & & 14.08 & 9.83 & 12.58 & 16.92 & \\
\hline LSD0.05 & $\mathrm{MF}=0.76$ & $41 \quad \mathrm{BH}$ & $=0.7641$ & $\mathrm{RF} \times \mathrm{BF}=1$ & 235 & $\mathrm{MF}=1.1$ & 481 & $=1.1481$ & $\mathrm{MF} \times \mathrm{BF}=$ & .398 \\
\hline \multicolumn{11}{|c|}{ Shoot fresh weight (g/plant) } \\
\hline Without inoculation & 117.33 & 83.53 & 112.90 & 135.33 & 112.27 & 143.59 & 103.00 & 145.00 & 170.25 & 140.46 \\
\hline Inoculation with PDB & 243.67 & 147.18 & 203.48 & 315.66 & 227.50 & 268.51 & 166.02 & 265.00 & 354.42 & 263.49 \\
\hline Inoculation with KSB & 237.33 & 125.15 & 189.33 & 279.37 & 207.80 & 250.94 & 177.38 & 250.69 & 313.61 & 248.15 \\
\hline $\begin{array}{l}\text { Inoculation with } \\
\text { PDB+KSB }\end{array}$ & 275.08 & 154.95 & 237.33 & 360.67 & 257.01 & 326.67 & 190.00 & 290.00 & 533.35 & 335.00 \\
\hline Mean & 218.35 & 127.70 & 185.76 & 272.76 & & 247.43 & 159.10 & 237.67 & 342.91 & \\
\hline LSD0.05 & $\mathrm{MF}=20.8$ & $11 \mathrm{BH}$ & $=20.811$ & $\mathrm{MF} \times \mathrm{BF}=1$ & .594 & $\mathrm{MF}=52$. & $921 \quad \mathrm{BF}$ & $=52.921$ & $\mathrm{MF} \times \mathrm{BF}=$ & .652 \\
\hline \multicolumn{11}{|c|}{ Shoot dry weight (g/plant) } \\
\hline Without inoculation & 28.85 & 22.58 & 27.72 & 30.35 & 27.38 & 36.67 & 33.42 & 36.24 & 37.94 & 36.07 \\
\hline Inoculation with PDB & 37.77 & 32.93 & 34.63 & 42.50 & 36.96 & 64.80 & 45.63 & 53.45 & 77.82 & 60.42 \\
\hline Inoculation with KSB & 36.26 & 32.22 & 32.28 & 40.68 & 35.36 & 61.71 & 44.40 & 51.78 & 69.69 & 56.89 \\
\hline $\begin{array}{l}\text { Inoculation with } \\
\text { PDB+KSB }\end{array}$ & 42.45 & 37.72 & 39.62 & 50.41 & 42.55 & 68.56 & 50.79 & 55.65 & 93.08 & 67.02 \\
\hline Mean & 36.33 & 31.36 & 33.56 & 40.99 & & 57.93 & 43.56 & 49.28 & 69.63 & \\
\hline LSD0.05 & $\mathrm{MF}=1.183$ & $36 \quad \mathrm{BH}$ & $=1.1836$ & $\mathrm{MF} \times \mathrm{BF}=1$ & 0517 & $\mathrm{MF}=5.1$ & $411 \quad \mathrm{BF}$ & $=5.1411$ & $\mathrm{MF} \times \mathrm{BF}=$ & 2317 \\
\hline \multicolumn{11}{|c|}{ Pant length $(\mathrm{cm})$} \\
\hline Without ino & 14.00 & 12.33 & 13.33 & 15.67 & 13.83 & 16.00 & 14.67 & 15.33 & 18.33 & 16.08 \\
\hline Inoculation with $\mathrm{PDB}$ & 17.33 & 15.00 & 15.67 & 18.67 & 16.67 & 20.67 & 16.33 & 18.00 & 23.67 & 19.67 \\
\hline Inoculation with KSB & 16.67 & 14.00 & 15.00 & 18.00 & 15.92 & 20.00 & 15.67 & 17.33 & 22.67 & 18.92 \\
\hline $\begin{array}{l}\text { Inoculation with } \\
\text { PDB+KSB }\end{array}$ & 17.67 & 15.33 & 16.33 & 21.00 & 17.58 & 23.00 & 17.00 & 20.00 & 28.00 & 22.00 \\
\hline Mean & 16.42 & 14.17 & 15.08 & 18.33 & & 19.92 & 15.92 & 17.67 & 23.17 & \\
\hline LSD0.05 & $\mathrm{MF}=0.995$ & $57 \quad \mathrm{BH}$ & 0.9957 & $\mathrm{MF} \times \mathrm{BF}=2$ & & $\mathrm{MF}=1$ & $86 \mathrm{BF}$ & .086 & $\mathrm{RF}-1$ & \\
\hline \multicolumn{11}{|c|}{ Plant fresh weight (g) } \\
\hline Without inoc & 263.63 & 207.77 & 250.32 & 283.38 & 251.28 & 295.75 & 233.82 & 289.55 & 329.47 & 287.15 \\
\hline Inoculation with PDB & 478.29 & 310.03 & 408.67 & 590.78 & 446.94 & 508.00 & 335.27 & 476.51 & 637.21 & 489.25 \\
\hline Inoculation with KSB & 462.56 & 284.48 & 384.37 & 546.05 & 419.37 & 482.42 & 344.96 & 452.89 & 587.62 & 466.97 \\
\hline $\begin{array}{l}\text { Inoculation with } \\
\text { PDB+KSB }\end{array}$ & 532.15 & 332.62 & 453.56 & 719.39 & 509.43 & 591.90 & 375.65 & 542.37 & 984.43 & 623.59 \\
\hline Mean & 434.16 & 283.73 & 374.23 & 534.90 & & 469.52 & 322.43 & 440.33 & 634.68 & \\
\hline LSD0.05 & $\mathrm{MF}=38.90$ & $08 \quad \mathrm{BH}$ & $==38.908$ & $\mathrm{MF} \times \mathrm{BF}=$ & 17.115 & $\mathrm{MF}=72$. & $431 \quad \mathrm{BF}$ & 72.431 & $\mathrm{MF} \times \mathrm{BF}=$ & .634 \\
\hline \multicolumn{11}{|c|}{ Plant dry weight (g) } \\
\hline Without i & 72.39 & 55.02 & 68.45 & 76.26 & 68.03 & 85.81 & 73.29 & 83.27 & 89.23 & 82.90 \\
\hline Inoculation with PDB & 93.24 & 71.40 & 86.39 & 105.63 & 89.17 & 126.99 & 98.56 & 111.56 & 151.04 & 122.04 \\
\hline Inoculation with KSB & 89.44 & 68.59 & 77.62 & 100.91 & 84.14 & 120.79 & 95.33 & 107.03 & 138.33 & 115.37 \\
\hline $\begin{array}{l}\text { Inoculation with } \\
\text { PDB+KSB }\end{array}$ & 110.12 & 85.18 & 99.03 & 121.88 & 104.05 & 142.57 & 109.03 & 126.78 & 181.06 & 139.86 \\
\hline Mean & 91.30 & 70.05 & 82.87 & 101.17 & & 119.04 & 94.05 & 107.16 & 139.91 & \\
\hline LSD0.05 & $\mathrm{MF}=2.45$ & $9 \quad \mathrm{BF}=$ & $.459 \mathrm{MI}$ & $\mathrm{F} \times \mathrm{BF}=1.3$ & & $\mathrm{MF}=7.5^{\prime}$ & 738 & 7.5738 & $\mathrm{MF} \times \mathrm{BF}=$ & 7989 \\
\hline
\end{tabular}

$* \mathrm{RD}=$ recommended dose; $62 \mathrm{kgP}_{2} \mathrm{O}_{5}+100 \mathrm{kgK}_{2} \mathrm{O} /$ fed as calcium super phosphate $\left(15.5 \% \mathrm{P}_{2} \mathrm{O} 5\right)+$ potassium sulfate $\left(50 \% \mathrm{~K}_{2} \mathrm{O}\right)$, $\mathrm{RP}=62 \mathrm{kgP}_{2} \mathrm{O}_{5}$ as rock phosphate \& $\mathrm{RK}=100 \mathrm{kgK}_{2} \mathrm{O} /$ fed as rock feldspar $* *$ PDB; phosphate dissolving bacteria (Bacillus megaterium), KSB; potassium soluiblizing bacteria (Bacillus Coagulans) 
It is worth mention that the manufacture chemical fertilizer of $\mathrm{P}$ and $\mathrm{K}$ at recommended dose (RD) followed the dual soil application of RP+RK concerning their effect on the different studied vegetative growth parameters.

Regarding to the effect of bio-fertilizers, there were significant differences among most of all the treatments of bio-fertilizers i.e. without inoculation, phosphorussolubilizing bacteria (PDB), potassium-solubilizing bacteria (KSB) and PDB+KSB (table, 2). The highest significant effects on the studied vegetative growth were observed at the dual soil application of (PDB+KSB). The highest values i.e. (13.58 and 15.17), (257.0 and 335.0), (42.55 and 67.02), (17.58 and 22.00), (509.43 and 623.59) and (104.05 and 139.86) for shoot length $(\mathrm{cm})$, shoot fresh weight ( $\mathrm{g} / \mathrm{plant})$, shoot dry weight $(\mathrm{g} /$ plant$)$, plant length $(\mathrm{cm})$, plant fresh weight $(\mathrm{g})$ and plant dry weight $(\mathrm{g})$ in the first and second seasons, respectively.

The most significant interaction treatment effect was the mixed of dual application of $\mathrm{P}$ and $\mathrm{K}$ mineral natural fertilizer $(\mathrm{RP}+\mathrm{RK})$ and bio-fertilizers $(\mathrm{PDB}+\mathrm{KSB})$ in all growth parameters of table beet plant (table, 2). Through the average of both studied seasons, the interaction treatment $((\mathrm{RP}+\mathrm{RK})+(\mathrm{PDB}+\mathrm{KSB}))$ gave the highest significant increases percentage compared to $(\mathrm{RD}+$ no inoculation) i.e. $41.9,239.4,114.3,62.5,202.9$ and $89.7 \%$ for shoot length, shoot fresh weight, shoot dry weight, plant length, plant fresh weight and plant dry weight, respectively. The lowest increases percentages were due to $\mathrm{RP}+\mathrm{RK}$ over $\mathrm{RD}$, whereas the increases percentage due to (PDB+KSB) over no inoculation came in between (table, 3 ).

\section{Root Yield Parameters of Table Beet Plant:}

Data in Table 4 show that there were significant differences among most of all mineral fertilizer treatments i.e. chemical and natural fertilizers, where the dual soil application of RP+RK achieved the highest values i.e. (262.14and 291.77), (60.19 and 70.28), (17.83 and 21.31) and (7.945 and 9.277) for root fresh weight (g/plant), root dry weight (g/plant), root length $(\mathrm{cm})$, root dry yield (MT/fed), in the first and second grown seasons, respectively.

On the other hand, the sole application of RP had the lowest significant effect on all root yield parameters. It is worth mention that the manufacture chemical fertilizer of $\mathrm{P}$ and $\mathrm{K}$ at recommended dose (RD) followed the dual soil application of RP+RK concerning their effect on the different studied parameters of root yield.

Significant differences were revealed among most of all the treatments of bio-fertilizers i.e. without inoculation, phosphorus dissolving bacteria (PDB), potassium dissolving bacteria $(\mathrm{KSB})$ and $\mathrm{PDB}+\mathrm{KSB}$, concerning their effect on the different yield parameters. The dual soil application of PDB+KSB achieved the highest values i.e. (252.42 and 288.59), (61.51 and 72.84), (17.25 and 20.98) and (8.119 and 9.615) for root fresh weight ( $\mathrm{g} / \mathrm{plant})$, root dry weight ( $\mathrm{g} / \mathrm{plant}$ ), root length $(\mathrm{cm})$ and root dry yield (MT/fed), in the first and second grown seasons, respectively.

The most significant effect interaction treatments on yield and its parameters of table beet plant were the mixed of dual application of $\mathrm{P}$ and $\mathrm{K}$ mineral natural fertilizer $(\mathrm{RP}+\mathrm{RK})$ and biofertilizer $(\mathrm{PDB}+\mathrm{KSB})$, whereas the lowest one was the sole application of RP without inoculation of biofertilizer (table, 4).

Through the average of both studied seasons, the interacted treatments $((\mathrm{RP}+\mathrm{RK})+(\mathrm{PDB}+\mathrm{KSB}))$ gave the highest increased percentages compared to $(\mathrm{RD}+$ no inoculation) i.e. $89.2,53.4,46.2$ and $53.4 \%$ for root fresh weight, root dry weight, root length and root dry yield, respectively. The lowest increased percentages were due to $\mathrm{RP}+\mathrm{RK}$ over $\mathrm{RD}$, meanwhile the increased percentage due to $(\mathrm{PDB}+\mathrm{KSB})$ over no inoculation came in between (table, 5).

Table 3. Average of both studied seasons for the achieved increases percentage in growth parameters of Table beet compared to manufactured fertilizers and/or without biofertilizer inoculation.

\begin{tabular}{|c|c|c|c|}
\hline $\begin{array}{l}\text { Growth parameters } \\
\text { Treatments }\end{array}$ & $\begin{array}{l}\text { (RP+RK) } \\
\text { Vs RD }\end{array}$ & $\begin{array}{c}\text { (PDB+KSB) } \\
\text { Vs No inoculation }\end{array}$ & $\begin{array}{c}(\text { RP+RK) + (PDB+KSB) } \\
\text { Vs (RD + No inoculation) }\end{array}$ \\
\hline Shoot length $(\mathrm{cm})$ & 14.3 & 31.1 & 41.9 \\
\hline Shoot fresh weight (g/plant) & 31.8 & 133.7 & 239.4 \\
\hline Shoot dry weight (g/plant) & 16.5 & 70.6 & 114.3 \\
\hline Plant length $(\mathrm{cm})$ & 14.0 & 32.0 & 62.5 \\
\hline Plant fresh weight (g) & 29.2 & 110.0 & 202.9 \\
\hline Plant dry weight $(\mathrm{g})$ & 14.2 & 60.8 & 89.7 \\
\hline
\end{tabular}


Table 4. Effect of natural and bio-fertilizers on root yield parameters of table beet plant grown at two growth seasons.

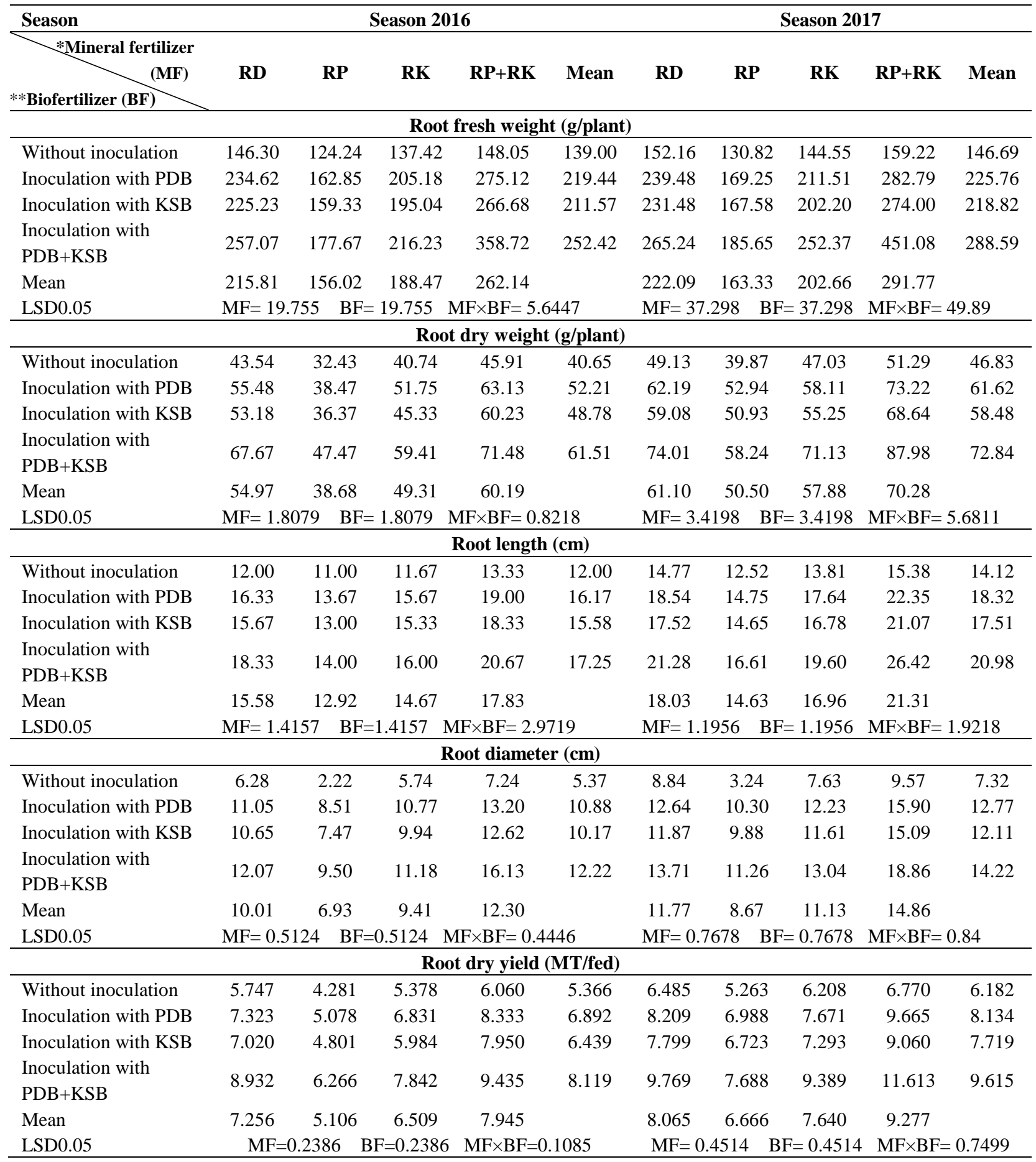

$* \mathrm{RD}=$ recommended dose; $62 \mathrm{kgP}_{2} \mathrm{O}_{5}+100 \mathrm{kgK}_{2} \mathrm{O} /$ fed as calcium super phosphate $\left(15.5 \% \mathrm{P}_{2} \mathrm{O} 5\right)+$ potassium sulfate $\left(50 \% \mathrm{~K}_{2} \mathrm{O}\right)$, $\mathrm{RP}=62 \mathrm{kgP}_{2} \mathrm{O}_{5}$ as rock phosphate \& $\mathrm{RK}=100 \mathrm{kgK}_{2} \mathrm{O} /$ fed as rock feldspar. ** PDB; phosphate dissolving bacteria (Bacillus megaterium), KSB; potassium soluiblizing bacteria (Bacillus Coagulans) 
Table 5. Average of both studied seasons for the achieved increases percentage in yield parameters of Table beet compared to manufactured fertilizers and/or without biofertilizer inoculation.

\begin{tabular}{lccc}
\hline Treatments & $\begin{array}{c}\text { (RP+RK) } \\
\text { Vs RD }\end{array}$ & $\begin{array}{c}\text { (PDB+KSB) } \\
\text { Vs No inoculation }\end{array}$ & $\begin{array}{c}\text { (RP+RK) + (PDB+KSB) } \\
\text { Vs (RD + No inoculation) }\end{array}$ \\
\hline Root fresh weight (g/plant) & 26.4 & 56.5 & 89.2 \\
Root dry weight (g/plant) & 12.3 & 33.2 & 53.4 \\
Root length (cm) & 16.3 & 31.0 & 46.2 \\
Root dry yield (MT/fed) & 12.3 & 33.2 & 53.4 \\
\hline
\end{tabular}

Mentioned above results are similar to those obtained by Artursson et al. (2006) and Marschner et al. (2010) who reported that the treatments that inoculated with bacteria, significantly, increased root growth, compared with control. In addition, Abou El Seoud et al. (2010) reported that the PDB have a significant effect on root yield of sugar beet.

The previous results are partially in agreement with many authors as follows; Han et al. (2005) noticed that application of rock $\mathrm{P}$ and $\mathrm{K}$ materials with coinoculation of both bacteria PDB+KSB that solubilize them and might provide faster and continuous supply of $\mathrm{P}$ and $\mathrm{K}$ for optimal plant growth. Similar results, Han et al. (2006) found that combined PDB inoculation with application of rock $\mathrm{P}$ consistently increased shoot and root dry weight as compared to control. Furthermore, growth enhancement by bacteria may be related to its ability to produce extensive root length (Sheng and Huang, 2002), improve root development and increase the rate of water and mineral uptake (Alexander, 1997 and Saghir et al., 2007). As regarded, Ibrahim et al. (2010) discussed the increase in the growth of the biofertilized trees as a result of the ability of $B$. megaterium to produce some growth promoting substances such as IAA, gibberellins and abscisic acid.

Table 6. Effect of natural and bio-fertilizers on yield quality of table beet grown at two growth seasons

\begin{tabular}{|c|c|c|c|c|c|c|c|c|c|c|}
\hline \multirow{2}{*}{$\begin{array}{l}\text { Season } \\
\text { *Mineral fertilize }\end{array}$} & \multicolumn{5}{|c|}{ Season2016 } & \multicolumn{5}{|c|}{ Season2017 } \\
\hline & RD & $\mathbf{R P}$ & RK & $\mathbf{R P}+\mathbf{R K}$ & Mean & RD & $\mathbf{R P}$ & RK & $\mathbf{R P}+\mathbf{R K}$ & Mean \\
\hline \multicolumn{11}{|c|}{ Root diameter $(\mathrm{cm})$} \\
\hline Without inoculation & 6.28 & 2.22 & 5.74 & 7.24 & 5.37 & 8.84 & 3.24 & 7.63 & 9.57 & 7.32 \\
\hline Inoculation with PDB & 11.05 & 8.51 & 10.77 & 13.20 & 10.88 & 12.64 & 10.30 & 12.23 & 15.90 & 12.77 \\
\hline Inoculation with KSB & 10.65 & 7.47 & 9.94 & 12.62 & 10.17 & 11.87 & 9.88 & 11.61 & 15.09 & 12.11 \\
\hline Inoculation with $\mathrm{PDB}+\mathrm{KSB}$ & 12.07 & 9.50 & 11.18 & 16.13 & 12.22 & 13.71 & 11.26 & 13.04 & 18.86 & 14.22 \\
\hline Mean & 10.01 & 6.93 & 9.41 & 12.30 & & 11.77 & 8.67 & 11.13 & 14.86 & \\
\hline LSD0.05 & \multicolumn{3}{|c|}{$\mathrm{MF}=0.5124 \quad \mathrm{BF}=0.5124$} & \multicolumn{2}{|c|}{$\mathrm{MF} \times \mathrm{BF}=0.4446$} & \multicolumn{2}{|c|}{$\mathrm{MF}=0.7678$} & $\mathrm{BF}=0.7678$ & \multicolumn{2}{|c|}{$\mathrm{MF} \times \mathrm{BF}=0.84$} \\
\hline \multicolumn{11}{|c|}{ Ascorbic acid (ppm) } \\
\hline Without inoculation & 5.57 & 6.04 & 6.12 & 6.33 & 6.01 & 5.71 & 6.20 & 6.27 & 6.49 & 6.17 \\
\hline Inoculation with PDB & 7.61 & 8.91 & 9.80 & 11.64 & 9.49 & 7.80 & 9.14 & 8.41 & 11.63 & 9.24 \\
\hline Inoculation with KSB & 7.40 & 8.63 & 9.62 & 10.62 & 9.07 & 7.59 & 8.85 & 9.22 & 11.58 & 9.31 \\
\hline Inoculation with $\mathrm{PDB}+\mathrm{KSB}$ & 8.46 & 9.28 & 10.43 & 12.75 & 10.23 & 8.68 & 9.51 & 10.72 & 13.25 & 10.54 \\
\hline Mean & 7.26 & 8.22 & 8.99 & 10.33 & & 7.45 & 8.43 & 8.65 & 10.74 & \\
\hline LSD0.05 & \multicolumn{3}{|c|}{$\mathrm{MF}=0.569 \mathrm{BF}=0.569 \mathrm{~N}$} & \multicolumn{2}{|c|}{$\mathrm{MF} \times \mathrm{BF}=0.6272$} & \multicolumn{3}{|c|}{$\mathrm{MF}=0.6208 \mathrm{BF}=0.6208$} & \multicolumn{2}{|c|}{$\mathrm{MF} \times \mathrm{BF}=0.6021$} \\
\hline \multicolumn{11}{|c|}{ TSS (\%) } \\
\hline Without inoculation & 8.36 & 8.64 & 8.93 & 11.39 & 9.33 & 8.57 & 8.86 & 9.15 & 11.34 & 9.48 \\
\hline Inoculation with PDB & 11.41 & 11.74 & 13.30 & 12.46 & 12.23 & 11.70 & 11.40 & 12.27 & 13.46 & 12.21 \\
\hline Inoculation with KSB & 11.10 & 12.01 & 13.37 & 13.80 & 12.57 & 11.38 & 12.33 & 12.46 & 14.39 & 12.64 \\
\hline Inoculation with $\mathrm{PDB}+\mathrm{KSB}$ & 12.70 & 12.93 & 14.22 & 14.58 & 13.61 & 13.02 & 12.60 & 13.31 & 15.22 & 13.54 \\
\hline Mean & 10.89 & 11.33 & 12.46 & 13.06 & & 11.17 & 11.30 & 11.80 & 13.60 & \\
\hline LSD0.05 & \multicolumn{2}{|c|}{$\mathrm{MF}=0.5486$} & $\mathrm{BF}=0.548$ & \multicolumn{2}{|c|}{$36 \mathrm{MF} \times \mathrm{BF}=0.835$} & \multicolumn{2}{|c|}{$\mathrm{MF}=0.3925$} & $\mathrm{BF}=0.3925$ & \multicolumn{2}{|c|}{$5 \mathrm{MF} \times \mathrm{BF}=0.7525$} \\
\hline
\end{tabular}

$* \mathrm{RD}=$ recommended dose; $62 \mathrm{kgP}_{2} \mathrm{O}_{5}+100 \mathrm{kgK}_{2} \mathrm{O} /$ fed as calcium super phosphate $\left(15.5 \% \mathrm{P}_{2} \mathrm{O} 5\right)+$ potassium sulfate $\left(50 \% \mathrm{~K}_{2} \mathrm{O}\right)$, $\mathrm{RP}=62 \mathrm{kgP}_{2} \mathrm{O}_{5}$ as rock phosphate $\& \mathrm{RK}=100 \mathrm{kgK}_{2} \mathrm{O} /$ fed as rock feldspar. ** PDB; phosphate dissolving bacteria (Bacillus megaterium), KSB; potassium soluiblizing bacteria (Bacillus coagulans) 
It is also well known that $B$. megaterium produces organic, inorganic acids and $\mathrm{CO}_{2}$ which lead to increase soil acidity and consequently convert the insoluble forms of phosphorus into soluble ones (Kucey, 1988; Alexander, 1997; Wani et al., 2007 and Adesemoye and Kloepper, 2009).

\section{Table Beet Yield and Quality Parameters:}

Data in Table 6 show that there were significant differences among most of all mineral fertilizer treatments i.e. chemical and natural fertilizers. The dual soil application of RP+RK achieved the highest values i.e. (12.30 and 14.86), (10.33 and 10.74) and (13.06 and 13.60) for root diameter (cm), ascorbic acid (ppm) and TSS (\%), in the $1^{\text {st }}$ and $2^{\text {nd }}$ seasons, respectively.

On the other hand, the sole application of RP had the lowest significant effect on all root yield quality parameters. It is worth mention that the manufacture chemical fertilizer of $\mathrm{P}$ and $\mathrm{K}$ at recommended dose (RD) followed the dual soil application of RP+RK concerning their effect on the different studied parameters of root yield quality.

Significant differences were noticed among most of all the treatments of bio-fertilizers i.e. without inoculation, phosphorus dissolving bacteria (PDB), potassium dissolving bacteria $(\mathrm{KSB})$ and $\mathrm{PDB}+\mathrm{KSB}$ concerning their effect on the different yield parameters. The dual soil application of PDB+KSB achieved the highest values i.e. (12.22 and 14.22), (10.23 and 10.54) and (13.61 and 13.54) for root diameter $(\mathrm{cm})$, ascorbic acid (ppm) and TSS (\%) in the first and second seasons, respectively.

The most significant effective interacted treatments were the mixed of dual application of $P$ and $K$ mineral natural fertilizer $(\mathrm{RP}+\mathrm{RK})$ and biofertilizer $(\mathrm{PDB}+\mathrm{KSB})$ on all yield quality parameters of table beet plant, whereas the lowest one was the sole application of RP without inoculation of biofertilizer (table, 6).

Through the average of both studied seasons, the interacted treatment $((\mathrm{RP}+\mathrm{RK})+(\mathrm{PDB}+\mathrm{KSB}))$ gave the highest increased percentage compared to $(\mathrm{RD}+$ no inoculation) i.e. $110.9,70.5$ and 58.0 for root diameter $(\mathrm{cm})$, ascorbic acid (ppm) and TSS (\%), respectively. The lowest increased percentage was due to RP+RK over $\mathrm{RD}$, meanwhile the increased percentage due to $(\mathrm{PDB}+\mathrm{KSB})$ over no inoculation came in between (table, 7).

The aforementioned results are in agreement with those obtained by Han et al. (2006); Sheng and Huang (2002); Alexander (1997) and Saghir et al. (2007). Ibrahim et al. (2010) mentioned that,the increment of the growth of biofertilizered trees may be due to the ability of $B$. megaterium to produce some growth promoting substances such as IAA, gibberellins and abscisic acid. It is also well known that $B$. megaterium produces organic, inorganic acids and $\mathrm{CO}_{2}$ which lead to increase soil acidity and consequently convert the insoluble forms of phosphorus into soluble ones (Kucey, 1988; Alexander, 1997; Wani et al., 2007 and Adesemoye and Kloepper, 2009).

\section{Available Phosphorus and Potassium In Soil}

Concerning the available phosphorus and potassium in soil (table, 8) it can be noticed that, there were significant differences among most of all mineral fertilizer treatments i.e. chemical and natural fertilizers, where the mineral chemical fertilizer of $\mathrm{P}$ and $\mathrm{K}$ at recommended dose (RD) gave the highest significant effects on available P (60.64 and $68.22 \mathrm{mgkg}^{-1}$ soil) and $\mathrm{K}\left(172.37\right.$ and $176.55 \mathrm{mgkg}^{-1}$ soil $)$ in the $1^{\text {st }}$ and $2^{\text {nd }}$ seasons, respectively, followed by the dual soil application of $\mathrm{p}$ and $\mathrm{K}$ mineral natural fertilizers (RP+RK).

The sole soil application of RK gave the lowest values for available $\mathrm{P}$ (32.59 and $44.05 \mathrm{mgPkg}^{-1}$ soil), while the lowest one for available K (150.77 and $160.38 \mathrm{mgkg}^{-1}$ soil) was due to the sole soil application of RK in the $1^{\text {st }}$ and $2^{\text {nd }}$ seasons, respectively. There were no significant differences between both sole soil application of RP and RK in the two studied seasons.

Concerning, their effect on the available phosphorus and potassium in soil, a significant differences among most of all inoculations treatments were noticed. It can be concluded that the dual inoculation $(\mathrm{PDB}+\mathrm{KSB})$ showed the highest significant effects on available $\mathrm{P}$ (48.23 and $59.97 \mathrm{mgkg}^{-1}$ soil) and $\mathrm{K}$ (185.95 and $191.54 \mathrm{mgkg}^{-1}$ soil) in the $1^{\text {st }}$ and $2^{\text {nd }}$ season, respectively.

The interacted treatment of the dual application of $\mathrm{P}$ and $\mathrm{K}$ mineral chemical at recommended dose (RD) with the dual application of bio-fertilizers (PDB+KSB) had the most significant effects on available $P$ and $K$ in soil, whereas the lowest one was due to the single application of RK without inoculation of biofertilizer.

In general, a large root surface area is the key importance for nutrient acquisition by roots (Marschner et al, 2010). An increase in root surface area can be either an inherent property or deficiency induced, such as $\mathrm{P}$ or K deficiency (Abou El Seoud et al., 2010). In this concern, Amer et al., (2010) stated that the increase in root surface area of common bean plants inoculated with $B$. subtilis was about 1.6-fold when compared with the common bean plants without inoculation. 
Table 7. Average of both studied seasons for the achieved increases percentage in root yield quality of Table beet compared to manufactured fertilizers and/or without biofertilizer inoculation.

\begin{tabular}{lccc}
\hline Treatments & $\begin{array}{c}\text { (RP+RK) } \\
\text { Vs RD }\end{array}$ & $\begin{array}{c}\text { (PDB+KSB) } \\
\text { Vs No inoculation }\end{array}$ & $\begin{array}{c}\text { (RP+RK) + (PDB+KSB) } \\
\text { Vs (RD + No inoculation) }\end{array}$ \\
\hline Root diameter (cm) & 24.6 & 76.9 & 110.9 \\
Ascorbic acid (ppm) & 43.2 & 57.2 & 70.5 \\
TSS\% & 49.0 & 53.7 & 58.0 \\
\hline
\end{tabular}

The obtained significant increases in $\mathrm{P}$ and $\mathrm{K}$ uptake when $\mathrm{P}$ and $\mathrm{K}$ were applied to the soil as rock phosphate and feldspar mixed with PDB may be due to that bacteria have been used to convert insoluble rock $\mathrm{P}$ and $\mathrm{K}$ material into soluble forms available for plant growth through acidification by producing strong organic acids (Nahas et al., 1990; Bojinova et al., 1997 and Schilling et al., 1998).

Similar results were obtained by Han et al., (2006) on pepper and cucumber plants and by Abarchi et al., (2009) on the legumes, Mucuna pruriens (L.) and Lablab purpureus (L.).

\section{Phosphorus and Potassium Content in Table Beet Plant:}

Data in Table 8 indicate that there were significant differences among all soil applications of mineral $\mathrm{P}$ and $\mathrm{K}$ fertilizers due to their effect on the content of $\mathrm{P}$ and $\mathrm{K}$ in table beet plant. The $\mathrm{P}$ and $\mathrm{K}$ mineral chemical fertilizers at recommended dose (RD) showed the highest significant effects on $\mathrm{P}(0.665$ and $0.706 \%)$ and $\mathrm{K}(2.50$ and $2.64 \%)$ in the $1^{\text {st }}$ and $2^{\text {nd }}$ seasons respectively, followed by the dual soil application of $\mathrm{P}$ and $\mathrm{K}$ mineral natural fertilizers $(\mathrm{RP}+\mathrm{RK})$. On the other hand, the lowest significant effects on $\mathrm{P}$ content $(0.447$ and $0.512 \%)$ was due to the sole soil application of mineral natural $\mathrm{K}(\mathrm{RK})$, whereas the lowest for $\mathrm{K}$ content (2.04 and $2.13 \%)$ were due to the single soil application of mineral natural $\mathrm{P}(\mathrm{RP})$, in the $1^{\text {st }}$ and $2^{\text {nd }}$ seasons, respectively.

Data in Table 8 indicate that there were significant differences among most of all soil applications of all inoculated treatments, where the dual inoculation PDB+KSB showed the highest significant effects on plant content of $\mathrm{P}(0.610$ and $0.659 \%)$ and $\mathrm{K}(2.53$ and $2.68 \%$ ) in the $1^{\text {st }}$ and $2^{\text {nd }}$ seasons, respectively.

It can be concluded that the interacted treatments of the dual application of $\mathrm{P}$ and $\mathrm{K}$ mineral chemical at recommended dose (RD) with the dual application of bio-fertilizers (PDB+KSB) had the most significant effects on $\mathrm{P}$ and $\mathrm{K}$ content (\%) in table beet plant, whereas the lowest were with the single application of RK without inoculation of biofertilizer (table, 8).
6. Phosphorus and Potassium Uptake by Table Beet Plant:

With respect to $\mathrm{P}$ and $\mathrm{K}$ uptake by table beet plant it can be concluded from results in Table 8 that the dual soil application $(\mathrm{RP}+\mathrm{RK})$ resulted in the highest significant effects on table beet $\mathrm{P}$ uptake $(0.572$ and 0.856 gplant $^{-1}$ ) and $\mathrm{K}$ uptake (2.312 and 3.504gplant ${ }^{-1}$ ) in the $1^{\text {st }}$ and $2^{\text {nd }}$ seasons, respectively, followed by the soil application of $\mathrm{P}$ and $\mathrm{K}$ mineral chemical fertilizers at recommended dose $(\mathrm{RD})$ for $\mathrm{P}$ uptake and $\mathrm{K}$ mineral natural fertilizer (RK) for K uptake.

The dual inoculation $\mathrm{PDB}+\mathrm{KSB}$ resulted in the highest significant effects on table beet $\mathrm{P}$ uptake $(0.629$ and 0.914 gplant $\left.^{-1}\right)$ and $\mathrm{K}$ uptake $(2.608$ and $3.734 \mathrm{~g}$ plant $^{-1}$ ) in the $1^{\text {st }}$ and $2^{\text {nd }}$ seasons, respectively.

The most significant effective interacted treatment was the mixed of dual application of $\mathrm{P}$ and $\mathrm{K}$ mineral natural fertilizer $(\mathrm{RP}+\mathrm{RK})$ and biofertilizer $(\mathrm{PDB}+\mathrm{KSB})$ on $\mathrm{P}$ and $\mathrm{K}$ uptake by table beet plant, whereas the lowest one was the sole application of RP without inoculation of biofertilizer.

These results are partially in accordance with those obtained by many authors such as Han and Lee (2005); Han et al. (2006); Takano et al. (2006); Chen et al. (2006); Eweda et al. (2007); Jorquera et al. 2008; Marschner (2009); Sabannavar and Lakshman (2009) and Marschner et al. (2010).

\section{The Microbial Densities and Dehydrogenase Activity In The Rhizosphere Of Table Beet:}

Regarding to the effect of natural mineral fertilizers compared to chemical one, data in Table 9 indicate that the dual soil application of RP+RK achieved the highest significant values i.e. (127.25 and 138.42), (112.04 and 128.67), ( 5.28 and 5.59), (101.17 and 108.17), (48.00 and 56.08) and (24.29 and 25.49) for total bacterial counts $\left(\mathrm{cfu} \times 10^{6} \mathrm{~g}^{-1}\right.$ dry soil), Bacillus megaterium density (counts $\times 103 \mathrm{cfu} / \mathrm{g}$ dry soil), Bacillus Coagulans density, total nitrifying bacterial count, total thermophilic bacterial count and dehydrogenase activity in the $1^{\text {st }}$ and $2^{\text {nd }}$ seasons, respectively. On the other hand, the sole application of RP had the lowest significant effect on all rhizosphere microbial activity parameters. 
Table 8. Effect of mineral natural and bio-fertilizers on available phosphorus and potassium in soil and their content and uptake in table beet plant grown at two growth seasons.

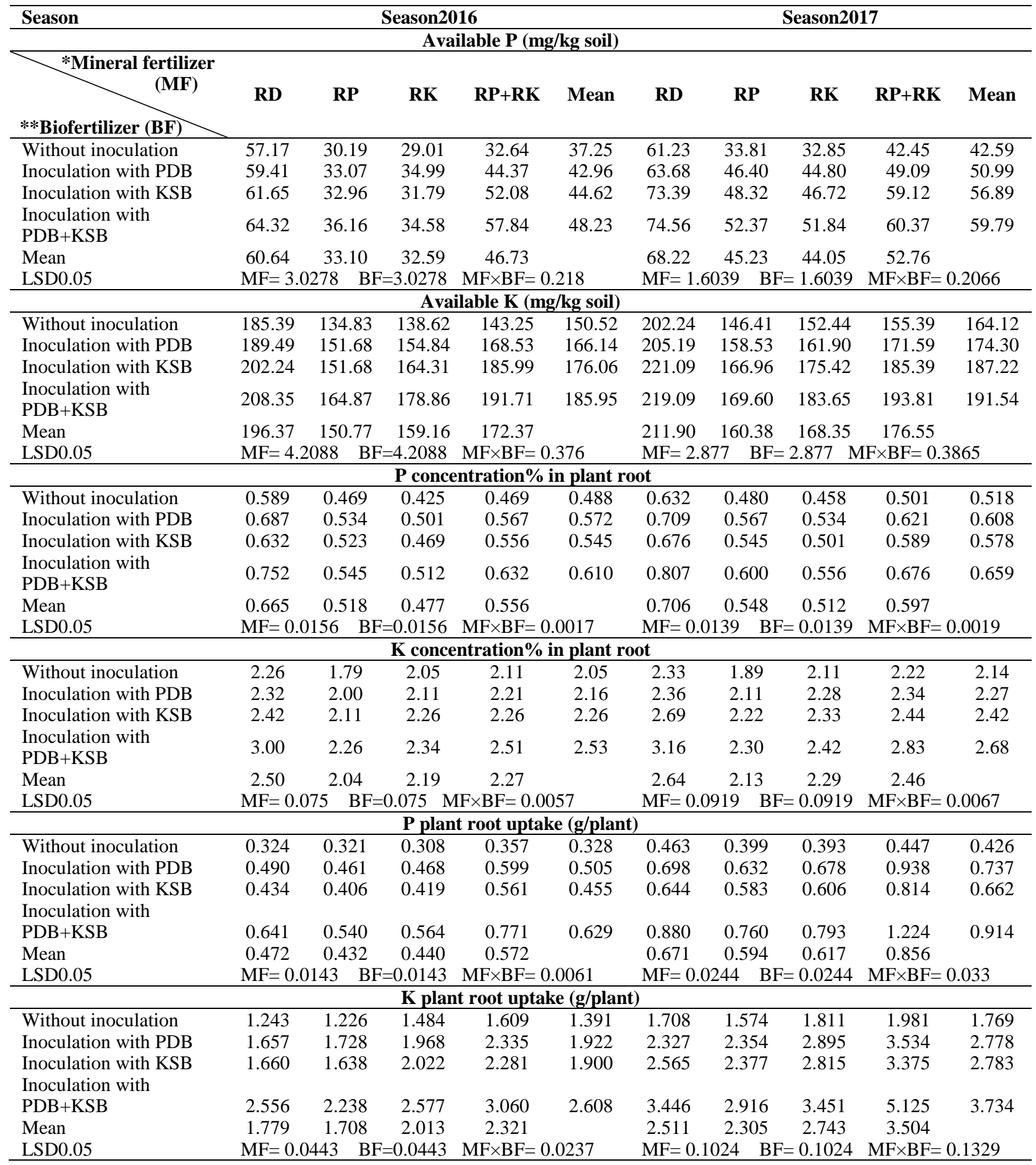

$* \mathrm{RD}=$ recommended dose; $62 \mathrm{kgP}_{2} \mathrm{O}_{5}+100 \mathrm{kgK}_{2} \mathrm{O} /$ fed as calcium super phosphate $\left(15.5 \% \mathrm{P}_{2} \mathrm{O} 5\right)+$ potassium sulfate $\left(50 \% \mathrm{~K}_{2} \mathrm{O}\right)$, $\mathrm{RP}=62 \mathrm{kgP}_{2} \mathrm{O}_{5}$ as rock phosphate $\& \mathrm{RK}=100 \mathrm{kgK}_{2} \mathrm{O} / \mathrm{fed}$ as rock feldspar. ** PDB; phosphate dissolving bacteria (Bacillus megaterium), KSB; potassium soluiblizing bacteria (Bacillus Coagulans). 
Table 9. Effect of natural and bio-fertilizers on the microbial densities and dehydrogenase activity in the rhizosphere of table Beet grown at two growth seasons.

\begin{tabular}{|c|c|c|c|c|c|c|c|c|c|c|}
\hline \multirow{2}{*}{$\underbrace{\text { Season }}_{* * \text { Biofertilizer }(\mathbf{B F})}$} & \multicolumn{5}{|c|}{ Season2016 } & \multicolumn{5}{|c|}{ Season2017 } \\
\hline & RD & $\mathbf{R P}$ & RK & $\mathbf{R P}+\mathbf{R K}$ & Mean & RD & $\mathbf{R P}$ & RK & RP+RK & Mean \\
\hline \multicolumn{11}{|c|}{ Total bacterial counts $\left(\mathrm{cfu} \times 10^{6} \mathrm{~g}^{-1}\right.$ dry soil $)$} \\
\hline Without inoculation & 85.67 & 58.00 & 75.00 & 98.00 & 79.17 & 90.33 & 62.67 & 79.67 & 102.00 & 83.67 \\
\hline Inoculation with PDB & 107.33 & 91.00 & 103.00 & 134.67 & 109.00 & 115.67 & 93.67 & 108.67 & 147.67 & 116.42 \\
\hline Inoculation with KSB & 106.00 & 88.00 & 104.00 & 131.67 & 107.42 & 114.00 & 92.67 & 109.00 & 144.67 & 115.08 \\
\hline Inoculation with $\mathrm{PDB}+\mathrm{KSB}$ & 118.00 & 98.00 & 110.67 & 144.67 & 117.83 & 124.00 & 105.67 & $7 \quad 118.00$ & 159.33 & 126.75 \\
\hline Mean & 104.25 & 83.75 & 98.17 & 127.25 & & 111.00 & 88.67 & $7 \quad 103.83$ & 138.42 & \\
\hline LSD0.05 & $\mathrm{MF}=2.5555$ & \multicolumn{4}{|c|}{$\mathrm{BF}=2.5555 \quad \mathrm{MF} \times \mathrm{BF}=2.8532$} & \multicolumn{3}{|c|}{$\mathrm{MF}=3.5412 \quad \mathrm{BF}=3.5412$} & \multicolumn{2}{|c|}{$\mathrm{MF} \times \mathrm{BF}=3.4784$} \\
\hline \multicolumn{11}{|c|}{ Phosphate dissolving bacteria count ( $\mathrm{cfu} \times 10^{4} \mathrm{~g}^{-1}$ dry soil) } \\
\hline Without inoculation & 57.31 & 45.00 & 66.24 & 72.65 & 60.30 & 81.57 & 54.40 & 75.67 & 89.13 & 75.19 \\
\hline Inoculation with PDB & 82.30 & 51.27 & 80.54 & 117.33 & 82.86 & 107.47 & 66.67 & 99.70 & 135.13 & 102.24 \\
\hline Inoculation with KSB & 80.21 & 52.53 & 82.08 & 118.55 & 83.34 & 106.37 & 68.30 & 103.90 & 137.40 & 103.99 \\
\hline Inoculation with $\mathrm{PDB}+\mathrm{KSB}$ & 102.57 & 66.70 & 99.68 & 139.64 & 102.15 & 128.27 & 79.20 & 117.03 & 153.00 & 119.38 \\
\hline Mean & 80.60 & 53.88 & 82.14 & 112.04 & & 105.92 & 67.14 & 99.08 & 128.67 & \\
\hline LSD0.05 & $\mathrm{MF}=6.4862$ & \multicolumn{4}{|c|}{$\mathrm{BF}=6.4862 \quad \mathrm{MF} \times \mathrm{BF}=5.0646$} & \multicolumn{3}{|c|}{$\mathrm{MF}=5.3995 \quad \mathrm{~B}$} & \multicolumn{2}{|c|}{$\mathrm{MF} \times \mathrm{BF}=2.927$} \\
\hline \multicolumn{11}{|c|}{ Potassium dissolving bacteria count $\left(\mathrm{cfu} \times 10^{3} \mathrm{~g}^{-1}\right.$ dry soil $)$} \\
\hline Without in & 2.71 & 3.82 & 3.45 & 3.97 & 3.49 & 3.05 & 4.11 & 3.68 & 4.20 & 3.76 \\
\hline Inoc & 3. & 4.60 & 4.26 & & 4.31 & 3.6 & 4.95 & 4 & 5. & 4 \\
\hline Inoculation $\mathrm{v}$ & 3.7. & 5.01 & 4.62 & 5. & 4.73 & 3.87 & 5.38 & 4.79 & 5.78 & 4.96 \\
\hline Inoculation with PDB+KSB & 4.37 & 5.88 & 5.58 & 6.4 & 5.57 & 4.58 & 6.10 & 5.89 & 6.94 & 5.88 \\
\hline Mean & 3.52 & 4.83 & 4.48 & 5.28 & & 3.78 & 5.14 & 4.72 & 5.59 & \\
\hline LSD0.05 & \multicolumn{5}{|c|}{$\mathrm{MF}=0.0502 \mathrm{BF}=0.0708 \mathrm{MF} * \mathrm{BF}=0.1417$} & \multicolumn{5}{|c|}{$\mathrm{MF}=0.0399 \mathrm{BF}=0.0782 \mathrm{MF} * \mathrm{BF}=0.1410$} \\
\hline \multicolumn{11}{|c|}{ Total nitrifying bacterial count } \\
\hline Without ino & 53.00 & 38.00 & 40.67 & 59.00 & 47.67 & 55.33 & 43.00 & 43.67 & 60.67 & 50.67 \\
\hline Inoculation $\mathrm{y}$ & 99.00 & 58.00 & 81.00 & 116.67 & 88.67 & 107.33 & 63.67 & 97.67 & 119.00 & 96.92 \\
\hline Inoculation with KSB & 93.33 & 55.00 & 82.67 & 104.67 & 83.92 & 108.33 & 64.33 & 98.00 & 120.33 & 97.75 \\
\hline Inoculation with $\mathrm{PDB}+\mathrm{KSB}$ & 103.33 & 61.67 & 86.33 & 124.33 & 93.92 & 112.33 & 75.33 & 104.00 & 132.67 & 106.08 \\
\hline Mean & 87 & 53.17 & 72.67 & 101.17 & & 95.83 & 61.58 & 85.83 & 108.17 & \\
\hline LSD0.05 & $\mathrm{MF}=6.0722$ & $\mathrm{BF}=6.07$ & $722 \mathrm{MF}$ & $\times \mathrm{BF}=5.377$ & & $\mathrm{MF}=6.2$ & $191 \mathrm{~B}$ & $\mathrm{BF}=6.2191$ & $\mathrm{MF} \times \mathrm{BF}$ & $=3.8$ \\
\hline \multicolumn{11}{|c|}{ Total thermophilic bacterial count } \\
\hline With & 36.33 & 31.33 & 34.67 & 39.00 & 35.33 & 42.33 & 38.33 & 39.67 & 48 & 42.25 \\
\hline Inocu & 46.67 & 35.33 & 37.67 & 50.67 & 42.58 & 49.67 & 41.67 & 43.00 & 55.00 & 47.33 \\
\hline Inoculation with KSB & 44.33 & 35.67 & 38.33 & 49.00 & 41.83 & 49.33 & 42.33 & 43.67 & 54.33 & 47.42 \\
\hline Inoculation with $\mathrm{PDB}+\mathrm{KSB}$ & 47.33 & 36.67 & 42.00 & 53.33 & 44.83 & 59.67 & 45.00 & 50.67 & 66.33 & 55.42 \\
\hline Mean & 43.67 & 34.75 & 38.17 & 48.00 & & 50.25 & 41.83 & 44.25 & 56.08 & \\
\hline LSD0.05 & $\mathrm{MF}=1.708$ & $\mathrm{BF}=1.708$ & $3 \mathrm{MF} \times \mathrm{B}$ & $\mathrm{F}=2.1954$ & & $\mathrm{MF}=1.8$ & $396 \quad \mathrm{~B}$ & $\mathrm{BF}=1.8396$ & $\mathrm{MF} \times \mathrm{BF}=$ & $=2.1284$ \\
\hline \multicolumn{11}{|c|}{ Dehydrogenase activity ( $\mu \mathrm{g}$ TPF g- ${ }^{1}$ dry soil 24h.) } \\
\hline Without inoculation & 3.79 & 2.04 & 2.73 & 4.64 & 3.30 & 4.35 & 2.27 & 2.88 & 5.72 & 3.80 \\
\hline Inoculation with PDB & 15.87 & 8.16 & 10.68 & 28.82 & 15.88 & 16.75 & 8.37 & 11.77 & 29.25 & 16.54 \\
\hline Inoculation with KSB & 12.85 & 6.86 & 11.21 & 27.22 & 14.53 & 15.82 & 8.05 & 12.05 & 28.31 & 16.06 \\
\hline Inoculation with $\mathrm{PDB}+\mathrm{KSB}$ & 21.91 & 9.16 & 12.25 & 36.47 & 19.95 & 23.17 & 9.74 & 13.15 & 38.67 & 21.18 \\
\hline Mean & 13.61 & 6.56 & 9.22 & 24.29 & & 15.02 & 7.10 & 9.96 & 25.49 & \\
\hline LSD0.05 & $\mathrm{MF}=3.3422$ & $\mathrm{BF}=3.34$ & $122 \quad \mathrm{MF}$ & $\times \mathrm{BF}=0.33 \mathrm{C}$ & & $\mathrm{MF}=3.3$ & $287 \quad \mathrm{~B}$ & $\mathrm{BF}=3.3287$ & $\mathrm{MF} \times \mathrm{BF}=$ & $=0.7561$ \\
\hline
\end{tabular}

$* \mathrm{RD}=$ recommended dose; $62 \mathrm{kgP}_{2} \mathrm{O}_{5}+100 \mathrm{kgK}_{2} \mathrm{O} /$ fed as calcium super phosphate $\left(15.5 \% \mathrm{P}_{2} \mathrm{O} 5\right)+$ potassium sulfate $\left(50 \% \mathrm{~K}_{2} \mathrm{O}\right)$, $\mathrm{RP}=62 \mathrm{kgP}_{2} \mathrm{O}_{5}$ as rock phosphate \& $\mathrm{RK}=100 \mathrm{kgK}_{2} \mathrm{O} / \mathrm{fed}$ as rock feldspar. $* *$ PDB; phosphate dissolving bacteria (Bacillus megaterium), KSB; potassium soluiblizing bacteria (Bacillus Coagulans)

The dual soil inoculation PDB+KSB achieved the highest significant values (117.83 and 126.75), (102.15 and 119.38), (5.569 and 5.879), (93.92 and 106.08), (44.83 and 55.42) and (19.95 and 21.18) for total bacterial count, Bacillus megaterium density (counts $\times 10^{3} \mathrm{cfu} / \mathrm{g}$ dry soil), Bacillus Coagulans density (counts $\times 10^{3} \mathrm{cfu} / \mathrm{g}$ dry soil), total nitrifying bacterial count, total thermophilic bacterial count and dehydrogenase activity 
$(\mu \mathrm{mol} / \mathrm{g}$ dry soil $/ \mathrm{hr}$.$) in the 1^{\text {st }}$ and $2^{\text {nd }}$ seasons, respectively.

It is worth mention that the manufacture chemical fertilizer of $\mathrm{P}$ and $\mathrm{K}$ at recommended dose (RD) followed the dual soil application of RP+RK concerning, their effect on the different studied rhizosphere microbial activity parameters.
The most significant effective interactied treatment was the mixed of dual application of $\mathrm{P}$ and $\mathrm{K}$ mineral natural fertilizer $(\mathrm{RP}+\mathrm{RK})$ and biofertilizer $(\mathrm{PDB}+\mathrm{KSB})$ on all parameters of the microbial densities and dehydrogenase activity in the rhizosphere of table beet, whereas the lowest one was the sole application of RP without inoculation of biofertilizer.

Table 10. Average of both studied seasons for the achieved increases percentage in the microbial densities and dehydrogenase activity in the rhizosphere of Table beet compared to manufactured fertilizers and/or without biofertilizer inoculation.

\begin{tabular}{lccc}
\hline \multicolumn{1}{c}{ Treatments } & $\begin{array}{c}\text { (RP+RK) } \\
\text { Vs RD } \\
\text { Rhizosphere microbial }\end{array}$ & $\begin{array}{c}\text { (PDB+KSB) } \\
\text { Vs No inoculation }\end{array}$ & $\begin{array}{c}\text { (RP+RK) + (PDB+KSB) } \\
\text { Vs (RD + No inoculation) }\end{array}$ \\
\hline Total bacterial counts (cfu X $10^{6} \mathrm{~g}^{-1}$ dry soil) & 23.4 & 36.8 & 50.2 \\
Phosphate dissolving bacteria count (cfu X $10^{4} \mathrm{~g}^{-1}$ dry soil) & 30.2 & 45.4 & 64.1 \\
Potassium dissolving bacteria count(cfu X $10^{3} \mathrm{~g}^{-1}$ dry soil) & 49.0 & 53.7 & 58.0 \\
Total nitrifying bacterial count & 14.5 & 54.9 & 103.2 \\
Total thermophilic bacterial count & 10.8 & 19.2 & 29.0 \\
Dehydrogenase activity ( $\mu \mathrm{g}$ TPF g- ${ }^{1}$ dry soil $\left.24 \mathrm{~h}.\right)$ & 74.1 & 287.1 & 481.0 \\
\hline
\end{tabular}

Table 11. Profitability per fed of Beta vulgare var Detrweet root yield (MT/fed) under varying understudied treatments of mineral and bio-fertilizers.

\begin{tabular}{clccccc}
\hline $\begin{array}{c}\text { Mineral } \\
\text { fertilizers }\end{array}$ & \multicolumn{1}{c}{ Biofertilizers } & $\begin{array}{c}\text { Yield } \\
\text { (MT/fed) }\end{array}$ & $\begin{array}{c}\text { Total } \\
\text { cost (LE) }\end{array}$ & $\begin{array}{c}\text { Total } \\
\text { income (LE) }\end{array}$ & $\begin{array}{c}\text { Net } \\
\text { Benefit (LE) }\end{array}$ & BCR \\
\hline \multirow{3}{*}{ RD } & Without inoculation & 6.116 & 6530 & 9174 & 2644 & 1.40 \\
& Inoculation with PDB & 7.766 & 6580 & 11649 & 5069 & 1.77 \\
& Inoculation with KSB & 7.410 & 6580 & 11114 & 4534 & 1.69 \\
& Inoculation with PDB+KSB & 9.351 & 6630 & 14026 & 7396 & 2.12 \\
\hline \multirow{5}{*}{ RP } & Without inoculation & 4.772 & 2350 & 7158 & 4808 & 3.05 \\
& Inoculation with PDB & 6.033 & 2400 & 9050 & 6650 & 3.77 \\
& Inoculation with KSB & 5.762 & 2400 & 8643 & 6243 & 3.60 \\
& Inoculation with PDB+KSB & 6.977 & 2450 & 10466 & 8016 & 4.27 \\
\hline \multirow{5}{*}{ RK } & Without inoculation & 5.793 & 3050 & 8690 & 5640 & 2.85 \\
& Inoculation with PDB & 7.251 & 3100 & 10877 & 7777 & 3.51 \\
& Inoculation with KSB & 6.639 & 3100 & 9958 & 6858 & 3.21 \\
& Inoculation with PDB+KSB & 8.616 & 3150 & 12923 & 9773 & 4.10 \\
\hline \multirow{5}{*}{ RP+RK } & Without inoculation & 6.415 & 3550 & 9623 & 6073 & 2.71 \\
& Inoculation with PDB & 8.999 & 3600 & 13499 & 9899 & 3.75 \\
& Inoculation with KSB & 8.505 & 3600 & 12758 & 9158 & 3.54 \\
& Inoculation with PDB+KSB & 10.524 & 3650 & 15786 & 12136 & 4.32 \\
\hline
\end{tabular}

$* \mathrm{RD}=$ recommended dose; $62 \mathrm{kgP}_{2} \mathrm{O}_{5}+100 \mathrm{kgK}_{2} \mathrm{O} /$ fed as calcium super phosphate $\left(15.5 \% \mathrm{P}_{2} \mathrm{O} 5\right)+$ potassium sulfate $\left(50 \% \mathrm{~K}_{2} \mathrm{O}\right)$, $\mathrm{RP}=62 \mathrm{kgP}_{2} \mathrm{O}_{5}$ as rock phosphate $\& \mathrm{RK}=100 \mathrm{kgK}_{2} \mathrm{O} / \mathrm{fed}$ as rock feldspar. ** PDB; phosphate dissolving bacteria (Bacillus megaterium), KSB; potassium soluiblizing bacteria (Bacillus Coagulans). 
Through the average of both studied seasons, the interacted treatment $((\mathrm{RP}+\mathrm{RK})+(\mathrm{PDB}+\mathrm{KSB}))$ gave the highest increased percentage as compared to $(\mathrm{RD}+$ no inoculation) i.e. 50.2, 64.1, 58.0,103.2 and $29.0 \%$ for Total bacterial counts $\left(\mathrm{cfu} \times 10^{6} \mathrm{~g}^{-1}\right.$ dry soil), phosphate dissolving bacterial count (cfu $\times 10^{4} \mathrm{~g}^{-1}$ dry soil), potassium dissolving bacterial count $\left(\mathrm{cfu} \times 10^{3} \mathrm{~g}^{-1}\right.$ dry soil), total nitrifying bacterial count, total thermophilic bacterial count and dehydrogenase activity $\left(\mu \mathrm{g}\right.$ TPF g- ${ }^{1}$ dry soil 24h.), respectively. The lowest increased percentages were due to RP+RK over RD of $\mathrm{P}$ and $\mathrm{K}$ chemical fertilizers, meanwhile the increased percentage due to $(\mathrm{PDB}+\mathrm{KSB})$ over no inoculation cleared in between (table, 10).

These results are partially in accordance with those obtained by many authors such as Han and Lee, (2005); Han et al., (2006); Takano et al., (2006); Chen et al., (2006); Eweda et al., (2007); Jorquera et al., 2008; Marschner, (2009); Sabannavar and Lakshman, (2009) and Marschner et al., (2010).

\section{Economic Value:}

Economic analysis of table beet root yield (MT/fed) under the varying understudied treatments of mineral and bio-fertilizers are shown in Table 11. Data indicated that application of bio-fertilizers either with chemical mineral or natural $\mathrm{P}$ and $\mathrm{K}$ resulted in higher benefit cost ratio (BCR) due to more income when compared to control (no inoculation). The combination treatment of $\mathrm{RP}+\mathrm{RK}+\mathrm{PDB}+\mathrm{KSB}$ gave the maximum total net profit (12236LE) and the maximum total $\mathrm{BCR}$ value (4.32) followed by the total BCR values (4.27 and 4.10) for both $\mathrm{RP}+\mathrm{PDB}+\mathrm{KSB}$ and $\mathrm{RP}+\mathrm{RK}+\mathrm{PDB}$ treatments, respectively. The plants without biofertilizer inoculation and $100 \%$ chemical PK (RD) resulted in smaller BCR values (1.40) due to lower net benefits (2644LE).

\section{REFERENCES}

Abarchi, I., B. Zhang Zhan-Yu, V.G. Xiang-Ping, W.Wei-Mu, B.T. Ong'or and D.Timbely. 2009. Effects of plant age and rock phosphate on quality and nutrient release of legume residue. Pedosphere 19 (1):78-85.

Abdel-Kader, A.A.S. and F.E.M. Saleh. 2017. Improvement of yield and quality of roselle (Hibiscus Sabdariffa 1.) Plant by using natural sources of phosphorus and potassium in calcareous sandy soils Scientific J. Flowers and Ornamental Plants. 4(3):233-244

Abou El Seoud, I.I. and A. Abdel-Megeed .2012. Impact of rock materials and biofertilizations on $\mathrm{P}$ and $\mathrm{K}$ availability for maize (Zea maize) under calcareous soil conditions. Saudi J. of Biol. Sci. 2012.1:55-63.
Abou El Seoud, I.I.A., A.B. Elham and A.E. El Shimaa. 2010.Response of two sugar beet varieties to chicken manure and phosphorine application. Alex. Sci. Exch. J. 30 (4): 433-444.

Adesemoye, A.O. and J.W. Kloepper. 2009. Plant-microbes interactions in enhanced fertilizer-use efficiency. Appl. Microbiol. Biotechnol. 85: 1-12.

Alexander, M.1997. Introduction to Soil Microbiology, second ed. John Wiley \& Sons Inc., New York.

Amer, M.A., I.I.A.Abou El Seoud, M.R.Rasmy and M. Manar. 2010. Biological control of Sclerotinia sclerotiorum, the casual agent of white basal rot disease of beans (Phaseolus vulgaris L.). Alex. Sci. Exch. J. 30. (4):334-339.

Aparna, B. 2001. Potassium status and enzymatic activities under different agro ecosystems of kerala. Proceedings of international symposium on importance of potassium in nutrient management for sustainable crop production in India. prii-ipi, New Delhi. INDIA.

Artursson, V., R.D. Finlay and J.K. Jansson. 2006. Interactions between arbuscular mycorrhizal fungi and bacteria and their potential for stimulating plant growth. Environ. Microbiol. 8:1-10.

Association of Official Agricultural Chemist (A.O.A.C). 1985. Official Methods of Analysis, 4thed. Washington, p. 832.

Badr, M.A., A.M. Shafei and S.H. Sharaf El-Deen. 2006. The dissolution of $\mathrm{K}$ and $\mathrm{P}$-bearing minerals by silicate dissolving bacteria and their effect on sorghum growth. Res. J. of Agric. and Biol. Sci., 2(1): 5-11.

Basha, A.A.A. and M.S. Hassan. 2017. Evaluation of rock phosphate and potassium feldspar with biological and organic amendments and its effect on soil phosphorus and potassium availability and uptake, growth and yield of canola. Inter. J. Plant and Soil Sci. 14(5): 1-14.

Becky, H., H. Martin and H. Joanna. 2001. How to optimize the drop plate method for enumerating bacteria. J. of Micro. Meth. 44:121-129.

Bogatyre, A.N. 2000. What are we to eat or how to live longer? Pishchevaya Promyshlennost. 7:34-35.

Bojinova, D., R. Velkova, I.Grancharov and S. Zhelev. 1997. The bioconversion of Tunisian phosphorite using Aspergillus niger. Nutr. Cycle Agroecosyst. 47:227-232

Chapman H.D. and P.F. Pratt. 1961. Methods of Analysis for Soils, Plants and Waters. Division of Agricultural Sciences, University of California, Riverside, USA.

Chen, Y.P., P.D. Rekha, A.B Arun, F.T.Shen, W.A. Lai and C.C.Young. 2006. Phosphate solubilizing bacteria from subtropical soil and their tricalcium phosphate solubilizing abilities. Appl. Soil Ecol. 34:33-41

EI-Naggar, H. M. 2010. Environmental engineering interventions to control the expansion of salty lakes and marshes in siwa oasis. J. Egypt Public Health Assoc. 85(34):223-45. 
Eman, S.A.; W.M. Abd El- Messeih and G.B. Mikhael. 2010. Using of natural raw material mixture and magnetite raw (magnetite iron) as substitute for chemical fertilizers in feeding "Le Conte" pear trees planted in calcareous soil. Alex. Sci. Exchange J., 31(1): 51- 62.

Eweda, W.E., S.M.Selim, M.I. Mostafa and D.A. Abd ElFattah. 2007. Use of Bacillus circulans as bio-accelerator enriching composted Agricultural wastes identification and utilization of the microorganism for compost production. In: Proceedings of the $12^{\text {th }}$ Conference of the Microbiology. Organized by The Egyptian Soc. of App. Micro. (ESAM), Giza, Egypt. 18-20. pp: 43-65.

Ferweez, H. and A. M. Abd El-Monem.2018. Enhancing Yield, Quality and Profitability of Sugar Beet Combining Potassium Fertilizer and Application Date of Yeast. Food Sci. Techn. Dept. and Agron. Dept., Fac. Agric. New Valley Branch, Assiut Univ., New Valley, Egypt.

Girgis, M.G.Z. 2006. Response of wheat to inoculation with phosphate and potassium mobilizers and organic amendment.Annals Agric. Sci., Ain Shams Univ., Cairo, 51(1): 85-100.

Gomez, K.A. and A.A. Gomez. 1984. Statistical procedures for agricultural research. 2nd Edition, john Willy and sons Inc. New York. pp: 680.

Hassan, A.M.F., A. Fawy , R.H. Hegab and N.M. Mohamed. 2016. Application of Manure and Phosphorus BioSolubilizers with Rock Phosphate in Calcareous Soils to Increase Phosphorus Availability and Productivity of Safflower Plant. Alex. Sci. Exch. J. 37: 799 - 810.

Han H.S. and K.D. Lee. 2005. Phosphate and potassium solubilizing bacteria effect on mineral uptake, soil availability and growth of eggplant. Res. J. Agric. Boil. Sci. 1(2):176-180.

Han, H.S., E. Supanjani and K.D. Lee. 2006. Effect of coinoculation with phosphate and potassium solubilizing bacteria on mineral uptake and growth of pepper and cucumber. Plant Soil Environ. 52 (3):130-136.

Hirotsugu, F., K. Asami, U. Norisuke, M. Kengoand T. Statoshi. 2015. Selective isolation of ammoniaoxidizing bacteria from autotrophic nitrifying granules by applying cell-sorting and sub-culturing of microcolonies. Front Microbiol. 6 . 1159. Doi: 10.3389/fmicb.201501159.

Hunter D., M. Foster, J. O. McArthur, R.Ojha, P. Petocz and S. Samman. 2011. Evaluation of the micronu-trient composition of plant foods produced by or-ganic and conventional agricultural methods. Cr. Rev. Food Sci. Nutr. 51: 571-582

Ibrahim, H.I.M., M.M.A. Zaglol, and A.M.M.Hammad. 2010. Response of Balady guava trees cultivated in sandy calcareous soil to biofertilization with phosphate dissolving bacteria and/or VAM fungi. J. Am. Sci. 6 (9): 399-404.

Idrees, M., M. A.Akbar and I. M. Javed . 2018.Potassium humate and NPK application rates influence yield and economic performance of potato crops grown in clayey loam soils. Soil Environ. 37(1): 53-61.
Jackson, M.L. 1973. Soil Chemical Analysis. Prentice-Hall of Indian Private, New Delhi.

Jorquera, M.A., M.T. Herna' ndez, Z. Rengel, P. Marschner and M.L.Mora. 2008. Isolation of culturable phosphobacteria with both phytate mineralization and phosphate-solubilization activity from the rhizosphere of plants grown in a volcanic soil. Biol. Fertil. Soils 44: 1025-1034

Kucey, R.M.N. 1988. Effect of Penicillium biloji on the solubility and uptake of $\mathrm{P}$ and micronutrients from soil by wheat. Can. J. Soil 68: 261-267.

Leisinger K.M. 1999. Biotechnology and food security, Curr. Sci. India 76:488-500.

Lin, Q.M., Z.H.Rao, Y.X.Sun, J.Yao and L.J. Xing. 2002. Identification and practical application of silicatedissolving bacteria. Agric. Sci. China 1: 81-85.

Maite, M., R. B. Asicent, L. Francisco and J. Juan. 2005. Bacteriophages May Bias Outcome of Bacterial Enrichment Cultures. Appl. Environ. Microbiol. 71 (8):4269-4275.

Marschner, A., Crowley, D.B., Rengel, Z., (2010). Interactions between rhizosphere microorganisms and plants governing iron and phosphorus availability. In: 19th World Congress of Soil Science, Soil Solutions for a Changing World, Brisbane, Australia.

Marschner, P. 2009. The role of rhizosphere microorganisms in relation to $\mathrm{P}$ uptake by plants. In: White, P.J., Hammond, J.P. (Eds.), The Ecophysiology of PlantPhosphorus Interactions, Plant Ecophysio. Series. Springer, Heidelberg, pp:165-176.

McLean, E.O. 1982. Soil pH and lime requirement. In: A. L. Page, R. H. Miller and D. R. Keeney (eds.) Methods of Soil Analysis. Am. Soc. Agronm. and Soil. Sci. Soc. Am. Madison, WI, USA:199- 224.

Miller, R.W., R.L. Donahue and J.U. Miller. 1990. Soils an Introduction to Soil and Plant Growth, Prentice Hall Inter Increase. Englewood Cliffs. New Jersy, pp:380-339.

Nahas, E., D.A. Banzatto and L.C.Assis. 1990. Fluorapatite solubilization by Aspergillus niger in vinasse medium. Soil Biol. Biochem. 22:1097-1101

Olsen S.R. and L.E. Sommers. 1982. Phosphorus. P. In: A. L. Page, R. H. Miller and D. R. Keeney (eds.) Methods of Soil Analysis. Am. Soc. Agronm. and Soil. Sci. Soc. Am. Madison, WI, USA:403-430.

Pious, T., C. Aparna, R. Sekhar, M. M. Upreti and S. P. Sadiq. 2015. Optimization of single plateserial dilution spotting (SP-SDS) with sample anchoring as an assured method for bacterial and yeast cfu enumeration and single colony isolation from diverse samples. Biotechnology Reports. 8: 45-55

Pramer, D. and E.L. Schmidt.1964. Experimental soil microbiology. Burgess Publ. Co., Minnesota, USA.

Rajan, S.S.S., J.H. Watkinson and A.G. Sinclair. 1996. Phosphate rock for direct application to soils. Adv. Agron. 57: 77- 159 . 
Rengel, $\mathrm{Z}$ and P. Damon. 2008. Crops and genotypes differ in efficiency of potassium uptake and use. Physiol. Plant., 133(4): 624-636.

Roghieh, H. and J. Arshad. 2009. The K/Na replacement and function of antioxidant defence system in sugar beet (Beta vulgaris L.) cultivars. Acta Agriculturae Scandinavica, 59(3): 246-259.

Sabannavar,S.J. and H.C.Lakshman. 2009. Effect of rock phosphate solubilization using mycorrhizal fungi and phosphobacteria on two high yielding varieties of Sesamum indicum L. World J. Agric. Sci. 5 (4): 470-479

Saghir, K.M., A.Zaidi and P.A. Wani. 2007. Role of phosphatesolubilizing microorganisms in sustainable agriculture: a review. Agron. Sustain. Dev. 27: 29-43.

Sahin, F., R. Çakmakçi and F. Kantar. 2004. Sugar beet and barley yields in relation to inoculation with $\mathrm{N}$-fixing and phosphate solubilizing bacteria. Plant Soil, 2 265: 123129.

Samotus B., M. Leja and A.Ścigalski. 1982. A comparison of four methods of determination of ascorbic acid in fruits and vegetables. Acta Agr. Silv., ser. Agr. 21: 105-121.

Schilling, G., A.Gransee, A. Deubel, G. Lezovic and S. Ruppel. 1998. Phosphorus availability, root exudates, and microbial activity in the rhizosphere. Z. Pflanzenernahr. Bodenkd. 161:465-478.

Sheng X.F. and W.Y. Huang. 2002. Mechanism of potassium release from feldspar affected by the strain NBT of silicate bacterium. Acta. Pedol. Sin. 39:863-871.

Sheng, X.F. and W.Y.Huang. 2002. Physiological characteristics of strain NBT of silicate bacterium. Acta Pedol. Sin. 38: 569-574.

Szura A., I. Kowalska and W. Sady. 2008. Biological value of red beets in relation to nitrogen fertilization. Veget. Crops Res. Bull. 68: 145-153. DOI: 10.2478/v10032-008-0013-4
Takano, Y., H. Mori, T. Kaneko, Y. Ishikawa, K. Marumo and K. Kobayashi. 2006. Phosphatase and microbial activity with biochemical indicators in semi-permafrost active layer sediments over the past 10, 000 years. Appl. Geochem. 21:48-57

Thalmann, A. 1967. Uber die microbiello Akivitat undihr Beziehung $\mathrm{Zu}$ fruchtbartkeits merkmalen eini-ger Acherboden unter besonderer Berucksi chtigung der dehydrogenase akativitat (TTC. Redukation). Biss Gieben PH.D.Thesis.W. Germany.

Vasil I.K. 1998. Biotechnology and Food security for 21st century: A real world perspective, Nat. Biotechnol. $16: 399-400$

Vessey, K.J. 2003. Plant growth promoting rhizobacteria as bio-fertilizers. Plant Soil 255:571-586.

Wani, P.A., M.S. Khan and A. Zaidi. 2007. Synergistic effects of the inoculation with nitrogen-fixing and phosphatesolubilizing rhizobacteria on the performance of fieldgrown chickpea. J. Plant Nutr. Soil Sci. 170:283-287.

WHO and Switzerland. 2017. Guidelines for DrinkingWater Quality. fourth edition incorporating the first addendum. Cataloguing-in-Publication. Interligar, Brazil, Data ISBN 978-92-4-154995-0.

Yagodin, B.A. 1990. Agricultural chemistry. Mir Publishers Moscow, pp:278-281.

Zhao, Y., D. Zhao and L.Daoliang. 2015. Electrochemical and Other Methods for Detection and Determination of Dissolved Nitrite: A Review. Int. J. Electrochem. Sci. 10: $1144-1168$.

Zujko M. E., A. Witkowska 2009. Antioxidant activity popular species fruits, vegetables, mushrooms and pulsem. Bromat. Chem. Toksykol. 3: 895-899. 


\section{الملخص العربي}

\section{تأثير الأسمدة الطبيعية والحيوية على إنتاجية وجودة بنجر المائدة النامى فى أرض رملية فى واحة سيوة مصر}

محمود على محمد السيد، محرم فؤاد عطية، محمد رائف حافظ

الطبيعية (RP + RK) وتوليفة الأسمدة الحيوية للبكتيريا الميسرة للفوسفور والمذيبة للبوتاسيوم (PDB + KSB) احيث

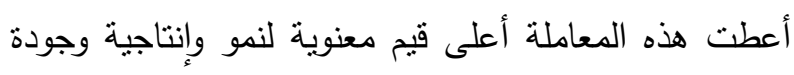

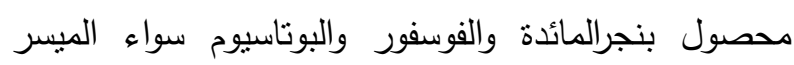
بالتزبة أو المنص بالنبات، وكذلك الكثافة الميكروبية ونشاط ولناط

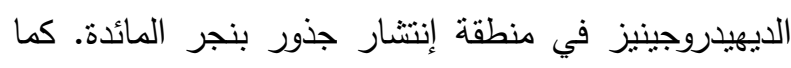

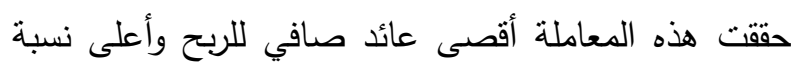

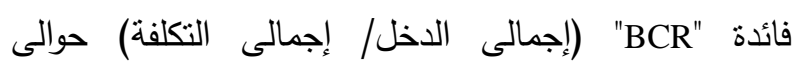

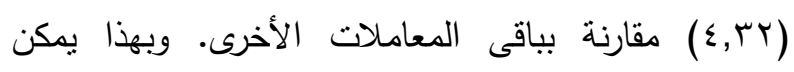

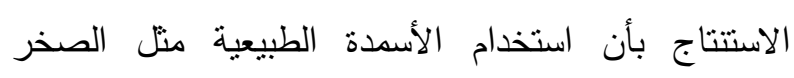
الفوسفاتى والبوتاسيومى مع الأسمدة الحيوية المئية الميسرة

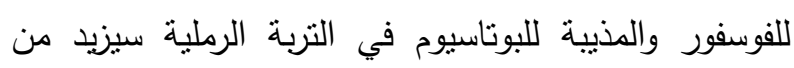

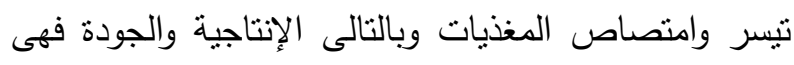

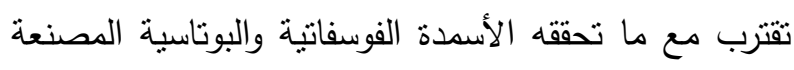

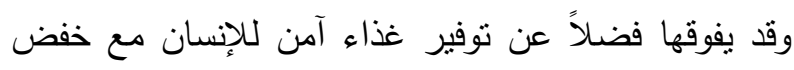

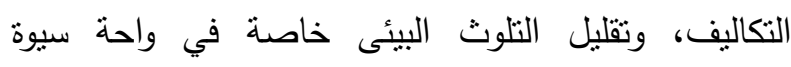
كمحبية طبيعية.
أجريت تجربة حقلية على بنجر المائدة صنف خلال موسمين متتابعين هما في في (Detrweet cv) 1T/Y.10

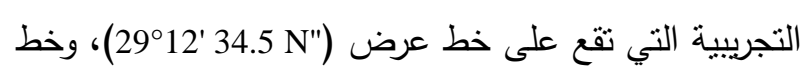
الطول (2.56" E 24'25)، في محطة بحوث سيوة، مركز بحوث الصحراء، مصر . أجريت التجربة الحقلية بتصميم

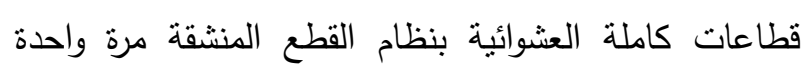

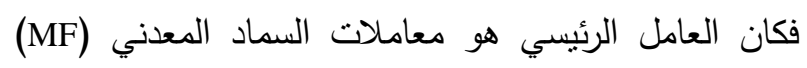

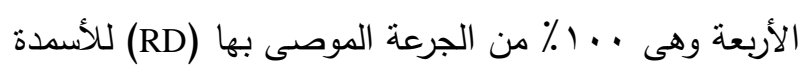

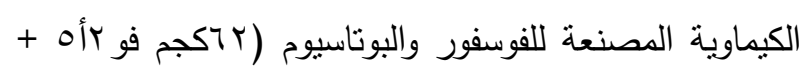

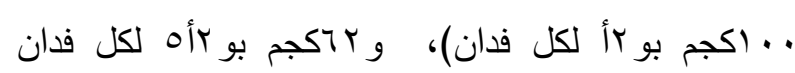

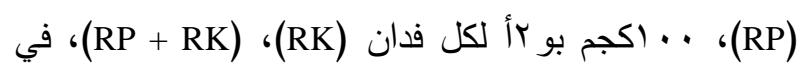

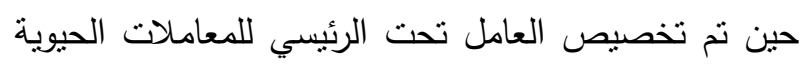

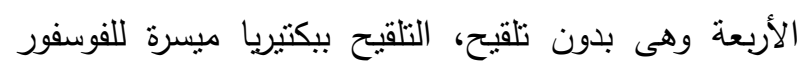
PDB )

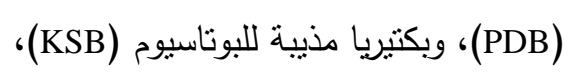

أنشارت الننائج إلى أن المعاملة الأكثر فاعلية هى معاملة التفاعل بين نوليفة أسمدة الفوسفور والبوتاسيوم المعدنية 